\title{
Investigation of new particle formation at the summit of Mt. Tai, China
}

\author{
Ganglin Lv ${ }^{1}$, Xiao Sui ${ }^{1}$, Jianmin Chen ${ }^{1,2}$, Rohan Jayaratne ${ }^{3}$, and Abdelwahid Mellouki ${ }^{1,4}$ \\ ${ }^{1}$ School of Environmental Science and Engineering, Environment Research Institute, Shandong University, Jinan, \\ Shandong 250100, China \\ ${ }^{2}$ Shanghai Key Laboratory of Atmospheric Particle Pollution and Prevention (LAP3), Institute of Atmospheric Sciences, \\ Fudan University, Shanghai 200433, China \\ ${ }^{3}$ International Laboratory for Air Quality and Health, Science and Engineering Faculty, Queensland University of \\ Technology, G.P.O. Box 2434, Brisbane, QLD 4001, Australia \\ ${ }^{4}$ Institut de Combustion, Aérothermique, Réactivité et Environnement, CNRS, 45071 Orléans CEDEX 02, France
}

Correspondence: Jianmin Chen (jmchen@fudan.edu.cn)

Received: 11 September 2016 - Discussion started: 24 October 2016

Revised: 26 December 2017 - Accepted: 5 January 2018 - Published: 15 February 2018

\begin{abstract}
To date, few comprehensive field observations of new particle formation (NPF) have been carried out at mountaintop sites in China. In this study, simultaneous measurements of particle size distribution, trace gases, meteorological parameters, and mass concentration and chemical composition of $\mathrm{PM}_{2.5}$ were performed at the summit of Mt. Tai (1534 ma.s.1.) from 25 July to 24 August 2014 (Phase I), 21 September to 9 December 2014 (Phase II), and 16 June to 7 August 2015 (Phase III) to investigate characteristics and favorable conditions of NPF in a relatively clean mountaintop environment. The NPF events were identified based on particle size distribution measured by the neutral cluster and air ion spectrometer (NAIS), and 66 such events were observed during a period of 164 days - corresponding to an occurrence frequency of $40 \%$. The formation rates of $3 \mathrm{~nm}$ particles $\left(J_{3}\right)$ and growth rates were in the ranges of $0.82-$ $25.04 \mathrm{~cm}^{-3} \mathrm{~s}^{-1}$ and $0.58-7.76 \mathrm{~nm} \mathrm{~h}^{-1}$, respectively. On average, the condensation sink (CS), $\mathrm{O}_{3}$ concentration, air temperature, and relative humidity were lower, whereas the $\mathrm{SO}_{2}$ concentration was higher on NPF days than that on non-NPF days. The CS on Mt. Tai was at a low level and lower CS was critical for NPF. NPF events were common when wind came from the east-southeast and west-southwest, which was probably associated with relatively lower CS in the east-southeast and higher $\mathrm{SO}_{2}$ concentration in the west-southwest. $\mathrm{O}_{3}$ was not a governing factor for NPF in this study, and a high level of $\mathrm{NO}_{x}$ concentration might be responsible for the de-
\end{abstract}

creased $\mathrm{O}_{3}$ concentration on NPF days. Three categories of backward trajectories were classified, among which the continental air mass was the majority. The continental air mass passing through more polluted areas (denoted as Type I) favored NPF because of enhanced $\mathrm{SO}_{2}$ concentration and potential ammonia with it. An in-depth analysis of $\mathrm{SO}_{2}$ indicated that sulfuric acid was a dominant precursor on Mt. Tai; meanwhile, biogenic organics released from ambient forests in warm seasons and anthropogenic volatile organic compounds emitted from domestic heating in cold seasons also promoted NPF.

\section{Introduction}

Atmospheric aerosols play a critical role in affecting global radiation forcing and climate (Kazil et al., 2010), directly through scattering and absorption of solar radiation, and indirectly by modifying cloud properties and lifetimes as the potential cloud condensation nuclei ( $\mathrm{CCN}$ ) (Kuang et al., 2010). Aerosol particles are also involved in several atmospheric chemistry processes such as enhancing haze and decreasing visibility, which are associated with air quality (Guo et al., 2014). In addition, aerosol particles can harm human health by inhalation (Han, 2012; Butt et al., 2016). Previous studies have shown that the nucleation of atmospheric gas-phase precursors and subsequent growth to larger parti- 
cles, widely known as new particle formation (NPF), is the largest source of atmospheric aerosol particles (Zhang et al., 2012). Field observations have exhibited that NPF typically increases the particle number concentration by a factor of 2 to 10 (Gong et al., 2010). Modeling studies also revealed that NPF accounted for $5-50 \%$ of CCN in the lower boundary layer (Spracklen et al., 2008). An in-depth study of the process of NPF and its effects contributes significantly to the pollution controls of atmospheric aerosols in China.

With development of instruments that measure particle size distribution, NPF events have been widely observed all over the world in recent decades. These observation sites include the northernmost sub-Arctic, remote boreal forests, industrialized agricultural regions, high-iodine coastal environments, and polluted urban areas (Dal Maso et al., 2002). The frequency of NPF events varies significantly between different locations. For example, Hallar et al. (2011) reported that NPF events in urban areas in Pittsburgh, USA, occurred about $35-50 \%$ during the observation period, whereas the corresponding values at the remote background sites in Finland and Sweden were just 2-27\%. Manninen et al. (2010) found that the frequency of NPF events ranged from 21 to $57 \%$ at 12 field sites around Europe, and number of observed NPF days was closely related to the regional atmospheric conditions. In addition, frequency of NPF events in a location is not constant. Wu et al. (2007) showed that NPF events occurred on 50,20,35, and $45 \%$ of days in spring, summer, autumn, and winter in Beijing, China.

In the past decade, many studies on NPF have been carried out in China. NPF events were first reported in China in 2004 by Wehner et al. (2004), who used a twin differential mobility particle sizer. Soon after, Liu et al. (2008) observed NPF at a rural and coastal site in Xinken (Guangdong Province). In 2005, Gao et al. (2009) investigated the occurrence of NPF in a suburban environment in the Yangtze River Delta using a wide-range particle spectrometer (WPS). Thereafter, several observations related to NPF have been widely reported in urban, suburban, and rural environments around China (An et al., 2015; Wang et al., 2011; Peng et al., 2014). At the remote high elevation sites, NPF might reveal some specific characteristics. Many mountain studies of NPF have been conducted around the world so far, for example at Mount Norikura in Japan, Jungfraujoch (3580 m a.s.1.) in Switzerland, Mt. Werner in the US, and the Himalayas in Nepal (Hallar et al., 2011; Chiharu et al., 2008; Weingartner et al., 1999; Venzac et al., 2008). At present, there have not been many observations at mountaintop sites in China. Before 2008 there had been no mountaintop observations of NPF in China. In 2008, Zhang et al. (2016) conducted the first mountaintop observation of NPF in China on Mt. Huang (1840 m a.s.l.) with a WPS instrument. However, these recent mountaintop studies in China were subject to great constraint in measurement methods. In this study, a neutral cluster and air ion spectrometer (NAIS), which could detect particle size distribution down than $3 \mathrm{~nm}$, was used. The NAIS greatly avoided the misleading interference of primary emission, and it measured more accurate particle formation sizes (Jayaratne et al., 2017).

Particle formation and growth rates vary with field environments. A review carried out by Kulmala et al. (2004) found that the typical formation rate was in the range of 0.01$10 \mathrm{~cm}^{-3} \mathrm{~s}^{-1}$. In urban areas it may be about $100 \mathrm{~cm}^{-3} \mathrm{~s}^{-1}$, while in coastal zones it can be as high as $10^{4}-10^{5} \mathrm{~cm}^{-3} \mathrm{~s}^{-1}$. The typical growth rate of newly formed particles ranges from 1 to $20 \mathrm{~nm} \mathrm{~h}^{-1}$, and at some coastal areas it is as high as $200 \mathrm{~nm} \mathrm{~h}^{-1}$.

Chemical mechanisms and precursor species related to NPF still remain uncertain, particularly under the highly complicated atmospheric environment. Previous studies have shown that sulfuric acid, ammonia, organics, and iodide species in the atmosphere were involved in the nucleation process under specific environments. Gaseous sulfuric acid is commonly the critical candidate participating in binary, ternary, and ion-induced nucleation (Boy et al., 2005; Wang et al., 2011; Zhang, 2010; Saunders et al., 2010; Allan et al., 2015). It has also been shown that nucleation rate can be a function of sulfuric acid concentration with a power dependency exponent, and its exponent varies significantly between different nucleation theories (Kulmala et al., 2006; Wang et al., 2011). However, the presence of a single sulfuric acid is always not enough to explain NPF in the atmosphere. Earlier studies indicated that ammonia and organics could enhance nucleation by stabilizing sulfuric acid-water clusters, and organics might exert more effectively at low concentration ( $\mathrm{Li}$ et al., 2017). In Zhang et al. (2004) and Zhang (2010), they showed that sulfuric acid and organic acid could form a stable organic acid-sulfuric acid complex that could efficiently reduce the nucleation barrier.

In addition to precursors, NPF in the atmosphere reveals the sensitivity of other factors, such as preexisting particles, meteorological conditions, and air mass transport. Preexisting particles contribute to a major sink for newly formed particles, and the large particle surface areas even probably act as a governing factor of NPF, as in the research of Cai et al. (2017) in Beijing. Comprehensive investigations of these factors on NPF in China have mainly been conducted in urban, suburban, and rural environments. Since mechanisms of NPF under the heavily polluted conditions are significantly different from those under relatively clean conditions (Kulmala et al., 2016; Hu et al., 2016; Wang et al., 2013), the comprehensive investigation of NPF at the relatively clean mountaintop site of Mt. Tai is of great importance.

In this paper, we present the results of intensive field observations at the summit of Mt. Tai (1534 m a.s.1.), which is a relatively clean mountaintop environment. This study was based on simultaneous measurements of particle size distribution, meteorological parameters, gaseous species, and mass concentration and chemical composition of $\mathrm{PM}_{2.5}$ during three campaigns (25 July to 24 August 2014, Phase I; 21 September to 9 December 2014, Phase II; 16 June to $7 \mathrm{Au}$ - 
gust 2015, Phase III). The general characteristics of NPF events, such as their start times, formation rates, and growth rates were discussed based on a more reliable nanometer instrument of the NAIS that can detect particles down to actual formation sizes. We explored the favorable conditions for NPF by analyzing factors, such as condensation sinks (CSs), and sources, meteorological conditions, and long-range air mass transport on NPF days and non-NPF days. In addition, potential precursor species were also investigated in this study.

\section{Methods}

\subsection{Site description}

The observations were conducted at the summit of Mt. Tai $\left(36.25^{\circ} \mathrm{N}, 117.1^{\circ} \mathrm{E}, 1534 \mathrm{~m}\right.$ a.s.l.), which is located nearly in the center of Shandong Province, eastern China. Mt. Tai is one of the highest mountains near the East China Sea on the transport path of the Asian continental outflow ( $\mathrm{Li}$ et al., 2011), adjacent to the Bohai Sea and Yellow Sea. The field site is just at the summit of Mt. Tai, and its surroundings are dominated by dense forests in summer and autumn with few anthropogenic primary emissions nearby. The nearest midsize city, Tai' an with a population of 670000 , is located approximately $15 \mathrm{~km}$ away to the south and southeast. The city of Jinan (population: 2800000 ), capital of Shandong Province, is $60 \mathrm{~km}$ to the north. During the daytime, the summit of Mt. Tai reaches close to the top of the planetary boundary layer, and the observation site is representative of the region (Zhang et al., 2014; Sun et al., 2016). All the instruments were installed inside a large trailer, and sampling was carried out through short inlet tubes outside the trailer at a height of about $3 \mathrm{~m}$ a.g.l. (above ground level).

\subsection{Measurement techniques}

Two types of particle size distribution instruments, namely a NAIS and a WPS, two gas monitors $\left(\mathrm{SO}_{2}\right.$ and $\left.\mathrm{O}_{3}\right)$, an instrument to measure mass concentration of $\mathrm{PM}_{2.5}$, and a monitor for chemical composition in $\mathrm{PM}_{2.5}$ were used in this study. In addition, meteorological parameters including air temperature $(T)$, relative humidity $(\mathrm{RH})$, wind speed, wind direction, and visibility were also recorded in real time.

The NAIS is a multichannel nanometer aerosol instrument that can measure the size distribution of aerosol particles and ions (charged particles and cluster ions) of both polarities simultaneously. The aerosol particle distribution of NAIS is in the size range of $2-40 \mathrm{~nm}$, and the ion distribution is in the electric mobility range of $0.0013-3.2 \mathrm{~cm}^{2} \mathrm{~V}^{-1} \mathrm{~s}^{-1}$ (equivalent to particle Millikan diameters of $0.8-40 \mathrm{~nm}$ ). The instrument consists of two multichannel electrical mobility analyzer columns, one for each polarity. The aerosols are classified according to electrical mobility and measured with an array of 21 electrometers per column. The total time of each measurement cycle was set at 5 min, comprising of sampling intervals as follows: particles every $120 \mathrm{~s}$, ions every $120 \mathrm{~s}$, and offset every $60 \mathrm{~s}$. The analysis of characteristics related to NPF in this study was mainly based on the data measured by NAIS.

The WPS is a high-resolution aerosol spectrometer that combines a differential mobility analyzer (DMA), a condensation particle counter (CPC), and a laser particle spectrometer (LPS). The diameter range of the WPS was from 10 to $10000 \mathrm{~nm} ; 48$ channels were used in the DMA and CPC, and 24 channels were used for the LPS. The scan time for the entire size range was set to $5 \mathrm{~min}$.

The concentration of $\mathrm{SO}_{2}$ in the atmosphere was measured with a pulsed ultraviolet fluorescence analyzer (model 43C, Thermo Electron Corporation - TEC), and $\mathrm{O}_{3}$ was measured with an ultraviolet photometric analyzer (model 49C, TEC). Mass concentration of $\mathrm{PM}_{2.5}$ was detected by a monitor utilizing a combination of beta attenuation and light scattering technology (model 5030 SHARP Monitor, Thermo Fisher Scientific), and chemical composition of $\mathrm{PM}_{2.5}$ was measured by a Monitor for Aerosols and Gases in Ambient Air (MARGA, ADI20801, Applikon-ECN, Netherlands). Meteorological data were obtained in real time with an automatic meteorological station (MILOS520, Vaisala, Finland).

\subsection{Data analysis}

\subsubsection{Formation rate, growth rate, and condensation sink}

In this study, particles in the size range of 3-20 nm were regarded as nucleation particles, and the formation rate of nucleation mode particles, $J_{3-20}$, can be expressed (Dal Maso et al., 2005) as

$J_{3-20}=\frac{\mathrm{d} N_{3-20}}{\mathrm{~d} t}+F_{\text {CoagS }}+F_{\text {growth }}$,

where $\mathrm{d} N_{3-20} / \mathrm{d} t$ is the net rate of increased nucleation mode particles, $F_{\text {Coags }}$ is the coagulation loss, and $F_{\text {growth }}$ is the loss of particles growing out of size range. In our observation, the $F_{\text {growth }}$ term could be neglected because particles growing beyond $20 \mathrm{~nm}$ before formation ended was relatively rare. In addition, the formation rate of $3 \mathrm{~nm}$ particles, $J_{3}$, was also calculated from the NAIS data (Sihto et al., 2006; Kulmala et al., 2012) by using Eq. (2):

$J_{3}=\frac{\mathrm{d} N_{3-6}}{\mathrm{~d} t}+\mathrm{CoagS}_{D p=4 \mathrm{~nm}} \cdot N_{3-6}+\frac{1}{3 \mathrm{~nm}} \mathrm{GR}_{3-6} \cdot N_{3-6}$,

where CoagS $\mathrm{S}_{D p=4 \mathrm{~nm}}$ represents the coagulation sink of $4 \mathrm{~nm}$ particles, an approximation for the interval of 3-6 nm particles. $\mathrm{GR}_{3-6}$ and $N_{3-6}$ denote the particle growth rate and particle number concentration between 3 and $6 \mathrm{~nm}$, respectively. 
The particle growth rate, GR, was determined with the maximum concentration method (Kulmala et al., 2012):

$\mathrm{GR}=\frac{\Delta D_{\mathrm{m}}}{\Delta t}=\frac{D_{\mathrm{m} 2}-D_{\mathrm{m} 1}}{t_{2}-t_{1}}$,

where $D_{\mathrm{m} 1}$ and $D_{\mathrm{m} 2}$ are the geometric median diameters of representative particles at the start time $t_{1}$ and the end time $t_{2}$, respectively.

CS determines the rate of molecule condensation on the preexisting aerosols, and it is given by Eq. (4) (Dal Maso et al., 2005; Kulmala et al., 2001):

$\mathrm{CS}=2 \pi D \sum_{i} \beta_{M_{i}} D p_{i} N_{i}$,

where $D$ is the diffusion coefficient for sulfuric acid, and $\beta_{M}$ is the size-dependent transitional correction factor.

\subsubsection{Sulfuric acid proxy}

Direct measurement of gas-phase sulfuric acid concentration was not available in this study. Instead, the predictive proxy for sulfuric acid $\left(\left[\mathrm{H}_{2} \mathrm{SO}_{4}\right]\right)$ could be roughly estimated based on the solar radiation (SR), $\mathrm{SO}_{2}$ concentration, $\mathrm{CS}$, and $\mathrm{RH}$ (Mikkonen et al., 2011):

$\left[\mathrm{H}_{2} \mathrm{SO}_{4}\right]=8.21 \times 10^{-3} \cdot k \cdot \mathrm{SR} \cdot\left[\mathrm{SO}_{2}\right]^{0.62} \cdot(\mathrm{CS} \cdot \mathrm{RH})^{-0.13}$.

Here $k$ is a temperature-dependent reaction rate constant, and the solar radiation is estimated from the Hybrid SingleParticle Lagrangian Integrated Trajectory (HYSPLIT) model developed by the NOAA Air Resources Laboratory. The absolute values of sulfuric acid concentration contain some error with the real concentrations because of large uncertainty in solar radiation from HYSPLIT, but its diurnal variation pattern is acceptable.

\section{Results and discussion}

\subsection{Classification and characteristics of NPF events}

Basically, an NPF event could be defined as a distinct burst of new nucleation-mode particles and subsequent growth of particles to a larger size over a period of time (Dal Maso et al., 2005; Hallar et al., 2011; D. W. Wang et al., 2014; Xiao et al., 2015). For the Mt. Tai observations in this study, neutral particles generally accounted for more than $95 \%$ of the total particles during NPF events; thus, the distribution of neutral particles will be discussed in this paper.

The data presented in this study covered three campaigns from 25 July to 24 August 2014 (Phase I), 21 September to 9 December 2014 (Phase II), and 16 June to 7 August 2015 (Phase III) at the summit of Mt. Tai. Observations over the 164 days showed that NPF events occurred on 66 days, corresponding to an occurrence frequency of $40 \%$. NPF events were frequently observed throughout the measurement campaigns, with a highest occurrence frequency of $56 \%$ during Phase II. In contrast, the average frequency was only $21 \%$ during the other two phases. This difference was mainly attributed to the rainy and foggy conditions of Phases I and III, which played the predominant role in hindering NPF.

In Fig. 1a, 1 month's set of continuous data from 10 November to 9 December 2014 for intensive NPF events was picked to take a closer look at the NAIS spectrogram, and the shaded areas represent NPF days. The spectrogram showed clear banana profiles on NPF days, and most events leveled off at about $30 \mathrm{~nm}$. These NPF events usually lasted hours, implying that NPF events mainly occurred on the regional scale.

In this study, we defined the observed start times of NPF events based on the significant enhancement of particle number concentration between 3 and $6 \mathrm{~nm}, N_{3-6}$. Results showed that approximately $95 \%$ of NPF events initiated at 08:0011:00 LT (local time) at the summit of Mt. Tai, which was in good agreement with many previous reports in China (Guo et al., 2012; An et al., 2015; Kulmala et al., 2016; Hao et al., 2015). The start times of NPF events at the summit of Mt. Tai were mainly associated with enhanced photochemical products in the early morning, generally corresponding to the sunrise. Since newly formed particles (about $1.4 \mathrm{~nm}$ ) need some time to grow to the measurable diameter, the real start times of NPF events would be earlier than the observed times above.

Table 1 lists the calculated parameters of all the NPF events observed at the summit of Mt. Tai, such as formation rate of nucleation-mode particles, formation rate of $3 \mathrm{~nm}$ particles, growth rate, CS, average sulfuric acid proxy concentration in the early morning (generally corresponding to the time period of 06:00-09:00 LT on Mt. Tai), $\mathrm{SO}_{2}$ concentration (06:00-13:00 LT), and $\mathrm{O}_{3}$ concentration (06:00-13:00 LT). Table 2 summarizes the averages, medians, 25th percentiles, 75th percentiles, minima, and maxima of these parameters on the basis of Table 1. Table 3 compares the characteristics of NPF on Mt. Tai in this study with some other studies in China.

The net increase rates and formation rates of nucleation mode particles on Mt. Tai were in the range of 0.96 48.52 and $1.10-57.43 \mathrm{~cm}^{-3} \mathrm{~s}^{-1}$, respectively. On average, coagulation loss accounted for $24.6 \%$ of the nucleationmode particle formation, which was significantly smaller than the result in Beijing in Yue et al. (2010). Coagulation could decrease the number concentration of newly formed particles, and a lower value of coagulation loss implied that NPF on Mt. Tai would contribute to higher CCN concentration. The maximum values of net increase rate, formation rate, and $\mathrm{SO}_{2}$ concentration all occurred on the same day 3 December 2014 - and $\mathrm{SO}_{2}$ concentration on this day was as high as $12.9 \pm 9.6 \mathrm{ppb}$. The formation rates $J_{3}$ varied from 0.82 to $25.04 \mathrm{~cm}^{-3} \mathrm{~s}^{-1}$, and their median, 25th percentile, and 75 th percentile were $6.15,3.31$, and $9.41 \mathrm{~cm}^{-3} \mathrm{~s}^{-1}$, re- 


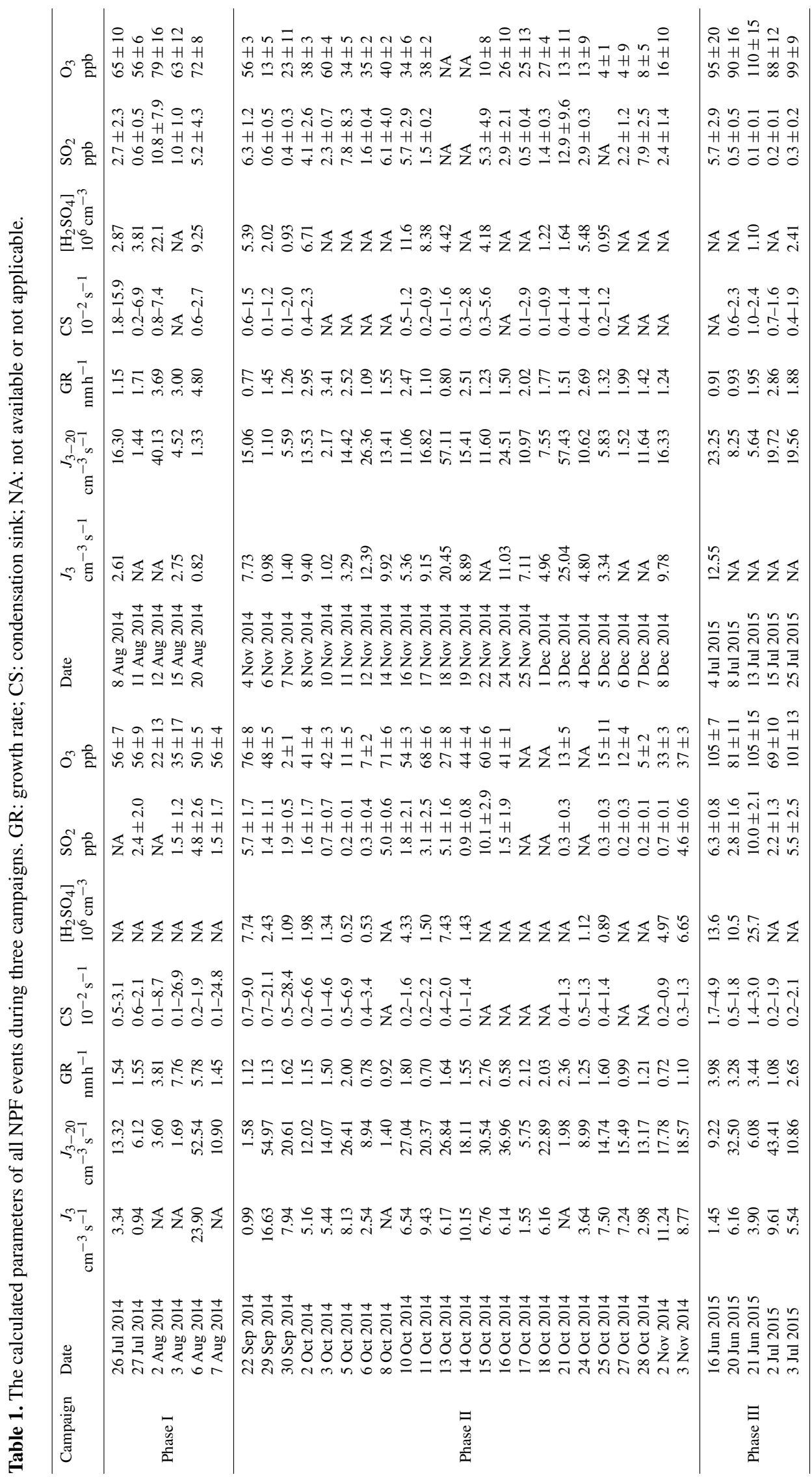



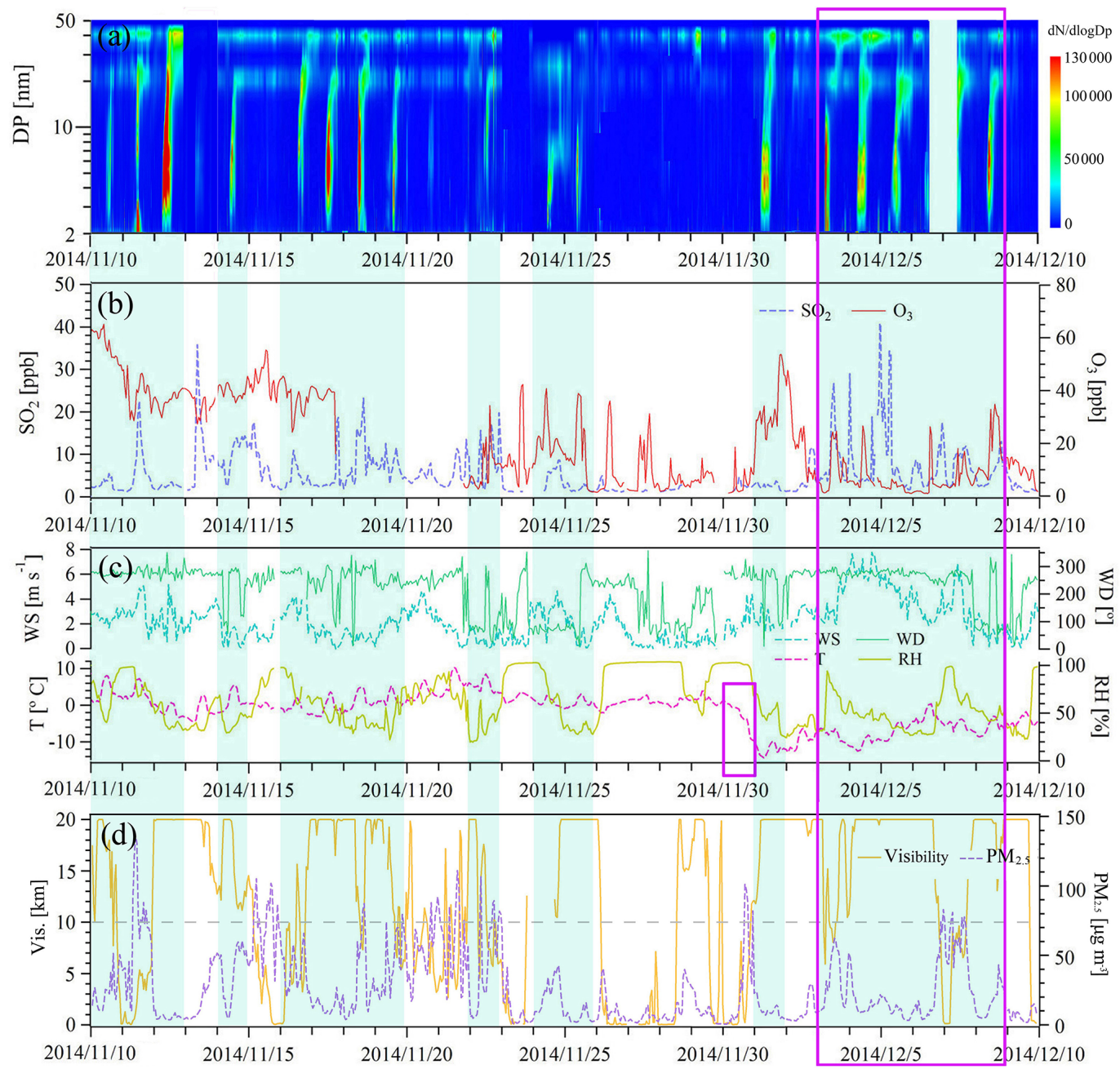

Figure 1. Time series during 10 November-9 December 2014, and the shaded areas represent NPF days: (a) contour plot of particle number size distribution using NAIS data; (b) sulfur dioxide (blue) and ozone (red); (c) meteorological parameters, including wind speed (cyan), wind direction (green), temperature (magenta), and relative humidity (earth yellow); (d) visibility (yellow) and $\mathrm{PM}_{2.5}$ concentration (purple). The gray line is the boundary for $10 \mathrm{~km}$ and $75 \mu \mathrm{g} \mathrm{m} \mathrm{m}^{-3}$.

Table 2. Summary of averages, medians, 25 th percentiles, 75 th percentiles, minima, and maxima for the calculated parameters.

\begin{tabular}{lrrrrrr}
\hline & Average & Minimum & Maximum & $\begin{array}{r}\text { 25th } \\
\text { percentile }\end{array}$ & Median & $\begin{array}{r}\text { 75th } \\
\text { percentile }\end{array}$ \\
\hline$J_{3}\left(\mathrm{~cm}^{-3} \mathrm{~s}^{-1}\right)$ & 7.10 & 0.82 & 25.04 & 3.31 & 6.15 & 9.41 \\
$J_{3-20\left(\mathrm{~cm}^{-3} \mathrm{~s}^{-1}\right)}$ & 16.61 & 1.10 & 57.43 & 6.12 & 13.47 & 20.61 \\
$\mathrm{GR}\left(\mathrm{nm} \mathrm{h}^{-1}\right)$ & 1.98 & 0.58 & 7.76 & 1.15 & 1.55 & 2.51 \\
$\mathrm{CS}\left(10^{-2} \mathrm{~s}^{-1}\right)$ & 1.4 & 0.1 & 28.4 & 0.5 & 0.9 & 1.7 \\
{$\left[\mathrm{H}_{2} \mathrm{SO}_{4}\right]\left(10^{6} \mathrm{~cm}^{-3}\right)$} & 5.23 & 0.52 & 25.7 & 1.28 & 3.34 & 7.07 \\
$\mathrm{SO}_{2}(\mathrm{ppb})$ & 3.2 & 0.1 & 12.9 & 0.7 & 2.2 & 2.7 \\
$\mathrm{O}_{3}(\mathrm{ppb})$ & 45 & 2 & 110 & 19 & 41 & 66 \\
\hline
\end{tabular}

spectively. On 3 December 2014, $J_{3}$ also peaked, suggesting that sulfuric acid was the governing precursor for this NPF event. As shown in Table 3, the particle formation rate at the summit of Mt. Tai was significantly higher than that on the hillside of Tai Mo Shan $\left(0.97-10.2 \mathrm{~cm}^{-3} \mathrm{~s}^{-1}\right)$ and on the top of Mt. Huang $\left(0.09-0.30 \mathrm{~cm}^{-3} \mathrm{~s}^{-1}\right.$ ) (Guo et al., 2012; Zhang et al., 2016), but lower than the results in Beijing and Shanghai (Xiao et al., 2015; Wang et al., 2015). In addition, 
Table 3. Comparison of NPF characteristics between Mt. Tai and other studies in China.

\begin{tabular}{|c|c|c|c|c|c|c|}
\hline Observation site & $\mathrm{FR}\left(\mathrm{cm}^{-3} \mathrm{~s}^{-1}\right)$ & $\mathrm{GR}\left(\mathrm{nm} \mathrm{h}^{-1}\right)$ & Freq. & Data & Air mass style & Ref. \\
\hline Mt. Tai & $7.10 \pm 5.39\left(J_{3}\right)$ & $1.98 \pm 1.27\left(\mathrm{GR}_{3-20}\right)$ & $40 \%$ & $\begin{array}{l}\text { Jul-Dec } 2014 \text { and } \\
\text { Jun-Aug } 2015\end{array}$ & Mountain (1534 m a.s.1.) & This study \\
\hline Tai Mo Shan & $0.97-10.2\left(J_{5.5}\right)$ & $1.5-8.4\left(\mathrm{GR}_{5.5-25}\right)$ & $33 \%$ & Oct-Nov 2010 & Mountain (640 m a.s.l.) & Guo et al. (2012) \\
\hline Mt. Huang & $0.09-0.30\left(J_{10}\right)$ & $1.42-4.53\left(\mathrm{GR}_{10-20}\right)$ & $37 \%$ & Apr-Jul 2008 & Mountain ( 1840 m a.s.l.) & Zhang et al. (2016) \\
\hline Mt. Huang & & $2.29-4.27\left(\mathrm{GR}_{10-15}\right)$ & $18 \%$ & Sep-Oct 2012 & Mountain ( 869 m a.s.1.) & Hao et al. (2015) \\
\hline Mt. Daban & & $0.8-3.2$ & $79 \%$ & Sep-Oct 2013 & Mountain (3295 m a.s.1.) & Du et al. (2015) \\
\hline $\begin{array}{l}\text { South Yellow Sea } \\
\text { and East China Sea }\end{array}$ & $0.3-15.2\left(J_{5.6-30}\right)$ & $2.5-5.0$ & $16 \%$ & $\begin{array}{l}\text { Oct-Nov } 2011 \\
\text { and Nov } 2012\end{array}$ & Marine & Liu et al. (2014) \\
\hline Backgarden & $2.4-4.0\left(J_{3-25}\right)$ & $4.0-22.7\left(\mathrm{GR}_{3-25}\right)$ & $25 \%$ & Jul 2006 & Rural & Yue et al. (2013) \\
\hline Nanjing & $2.6\left(J_{6}\right)$ & $10.4\left(\mathrm{GR}_{6-30}\right)$ & $44 \%$ & Dec 2011-Nov 2013 & Suburban & Qi et al. (2015) \\
\hline Lanzhou & & $1.2-16.9\left(\mathrm{GR}_{10-20}\right)$ & $33 \%$ & Jun-Jul 2006 & Suburban & Gao et al. (2012) \\
\hline Xinken & $0.5-5.2\left(J_{3-20}\right)$ & $2.2-19.8\left(\mathrm{GR}_{3-20}\right)$ & $26 \%$ & Oct-Nov 2004 & Suburban & Liu et al. (2008) \\
\hline Shanghai & $2.3-19.2\left(J_{3}\right)$ & $1.9-38.3\left(\mathrm{GR}_{7-20}\right)$ & $21 \%$ & Nov 2013-Jan 2014 & Urban & Xiao et al. (2015) \\
\hline Nanjing & $1.6-6.7\left(J_{10-25}\right)$ & $5.6-9.6\left(\mathrm{GR}_{10-25}\right)$ & $40 \%$ & Jul-Aug 2012 & Urban & An et al. (2015) \\
\hline Beijing & $5.0-44.9\left(J_{3}\right)$ & $1.86-6.7\left(\mathrm{GR}_{7-30}\right)$ & $26 \%$ & Jul-Sep 2008 & Urban & Wang et al. (2015) \\
\hline Lanzhou & $0.2-6.2\left(J_{14.6-25}\right)$ & $2.6-12.3\left(\mathrm{GR}_{14.6-25}\right)$ & $34 \%$ & Aug-Nov 2014 & Urban & Zhang et al. (2017) \\
\hline Qingdao & $13.3\left(J_{5.6-30}\right)$ & $2.0-10.2$ & $41 \%$ & Apr-May 2010 & Urban & Zhu et al. (2014) \\
\hline Hong Kong & $1.9\left(J_{5.5}\right)$ & $3.7-8.3\left(\mathrm{GR}_{5.5-10}\right)$ & $23 \%$ & Dec 2010-Jan 2011 & Urban & Wang et al. (2014) \\
\hline
\end{tabular}

the observed formation rate on Mt. Tai was slightly higher than the rural and suburban sites in Table 3 (Liu et al., 2008; Yue et al., 2013; Qi et al., 2015). Precursor concentrations on Mt. Tai should not be abundant compared with megacities such as Beijing, but the lower level of CS (detailed discussion in Sect. 3.2) on Mt. Tai could be partially responsible for the relatively high formation rate in this study.

Growth rates $\mathrm{GR}_{3-20}$ at the summit of Mt. Tai ranged from 0.58 to $7.76 \mathrm{~nm} \mathrm{~h}^{-1}$, and the median, 25 th percentile, and 75 th percentile were $1.55,1.15$, and $2.51 \mathrm{~nm} \mathrm{~h}^{-1}$, respectively. Growth rate on Mt. Tai was comparable with some other mountain observations such as $1.5-8.4 \mathrm{~nm} \mathrm{~h}^{-1}$ at Tai Mo Shan, $1.42-4.53 \mathrm{~nm} \mathrm{~h}^{-1}$ on Mt. Huang, and 0.8$3.2 \mathrm{~nm} \mathrm{~h}^{-1}$ on Mt. Daban (Du et al., 2015; Guo et al., 2012; Hao et al., 2015; Zhang et al., 2016). Growth rates observed at the rural, suburban, and urban sites were higher than the mountain observations shown in Table 3 (Yue et al., 2013; Liu et al., 2008; Gao et al., 2011; Qi et al., 2015; Xiao et al., 2015), suggesting that relatively clean mountain environments in this study contained insufficient vapors for subsequent particle growth.

\subsection{Condensation sinks and sources of NPF}

Classification of NPF events is associated with persistent high concentration of nucleation-mode particles, and occurrence of an NPF event is dependent on the competition between relevant sinks and sources. Newly formed particles are easily scavenged by larger preexisting particles in the atmosphere, leading to their continual reduction in particle number concentration. Conversely, a sufficiently high concentration of low volatility vapors (precursors) contributes to persistent nucleation, generating new atmospheric particles. Therefore, the CS and precursors are the key factors for NPF. As reported by Wang et al. (2011) and Guo et al. (2012), the lower CS and higher precursor concentrations are favorable for NPF. It is difficult to quantify the balance between the CS and precursors, and NPF events could be observed in many kinds of environments. For example, Kulmala et al. (2016) reported that NPF events could occur in some highly polluted Chinese megacities with high aerosol loadings. Zhu et al. (2014) showed that NPF events were observed in Qingdao City, where the high concentration of gaseous pollutants might offset the effect of a large CS. In a semirural location in India, Kanawade et al. (2014) also demonstrated that NPF events were not limited by a low value of CS alone. Therefore, the detailed analysis of sinks and sources at a specific site is of great importance for NPF.

In this study, CS on NPF days varied from $0.1 \times 10^{-2}$ to $28.4 \times 10^{-2} \mathrm{~s}^{-1}$, corresponding to the median, 25 th percentile, and 75 th percentile of $0.9 \times 10^{-2}, 0.5 \times 10^{-2}$, and $1.7 \times 10^{-2} \mathrm{~s}^{-1}$, respectively. The CS was much greater than $0.5 \times 10^{-3}-3.5 \times 10^{-3} \mathrm{~s}^{-1}$ in Hyytiälä, Finland (Dal Maso et al., 2005), but significantly lower than that at many locations in China, such as $0.6 \times 10^{-2}-8.4 \times 10^{-2} \mathrm{~s}^{-1}$ in Beijing, $0.9 \times 10^{-2}-3.9 \times 10^{-2} \mathrm{~s}^{-1}$ in Nanjing, $0.9 \times 10^{-2}-$ $5.3 \times 10^{-2}$ in Qingdao, and $1.0 \times 10^{-2}-6.2 \times 10^{-2} \mathrm{~s}^{-1}$ in Hong Kong (Zhang et al., 2011; Gao et al., 2012; Guo et al., 2012; An et al., 2015; Herrmann et al., 2014; Zhu et al., 2014). Overall, the general atmospheric environment at the summit of Mt. Tai was relatively clean in China with low particle loadings. The hourly average CS on nonNPF days was always higher than that on NPF days, being $(2.0 \pm 0.5) \times 10^{-2} \mathrm{~s}^{-1}$ and $(1.4 \pm 0.5) \times 10^{-2} \mathrm{~s}^{-1}$, respectively. This result indicated that the occurrence of NPF events at the summit of Mt. Tai was significantly influenced by lower CS.

Gas-phase sulfuric acid has been identified as the most important precursor for nucleation. Because direct emission of sulfuric acid is negligible at the summit of Mt. Tai, photo- 

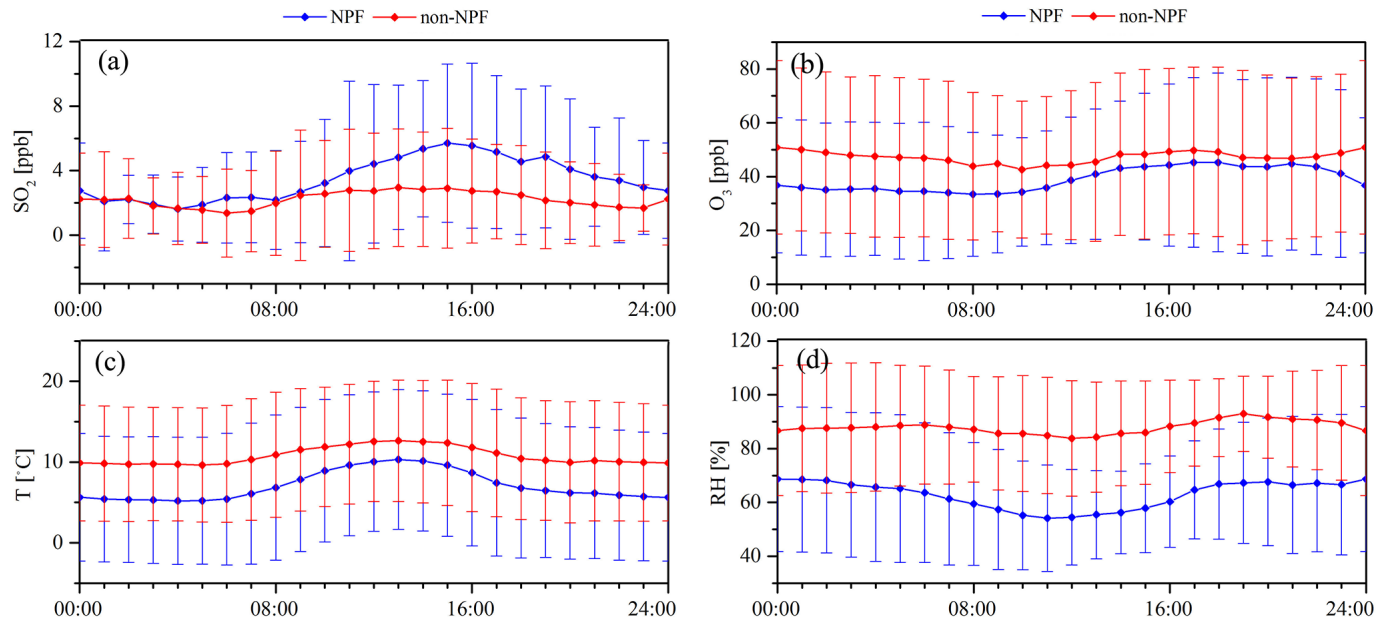

Figure 2. Average diurnal variations in trace gases $\left(\mathrm{SO}_{2}\right.$ and $\left.\mathrm{O}_{3}\right)$ and meteorological conditions ( $T$ and $\left.\mathrm{RH}\right)$ on NPF days and non-NPF days over all campaigns at the summit of Mt. Tai.

chemical reactions of $\mathrm{SO}_{2}$ would be the significant source for sulfuric acid in the atmosphere. As shown in Fig. 2a, $\mathrm{SO}_{2}$ concentration showed a sharp increase at sunrise, and almost all the hourly average $\mathrm{SO}_{2}$ concentrations on NPF days were higher than the corresponding values on non-NPF days (except for the slightly lower values at 01:00 and 03:00 LT). This indicated that sulfuric acid participated in NPF and played an important role for NPF initiation.

Figure 1 also showed visual correlations between particle number size distribution, gas species, meteorological parameters, and $\mathrm{PM}_{2.5}$ concentration. As discussed above, higher $\mathrm{SO}_{2}$ concentration can increase occurrence possibility of NPF events. The frequent NPF events in early December, for instance, could be attributed to enhanced $\mathrm{SO}_{2}$ concentration. In Fig. 1c, it was noteworthy that the temperature suddenly dropped from 1.3 to $-9.4^{\circ} \mathrm{C}$ on 30 November 2014. After several days, an exceptionally high $\mathrm{SO}_{2}$ concentration was observed $(7.1 \pm 7.2 \mathrm{ppb})$ at the summit of Mt. Tai (outlined in violet in Fig. 1), and frequent NPF events occurred during this period. A possible reason for this observation was the entrainment of $\mathrm{SO}_{2}$ from coal or petroleum combustion in the upwind region when temperature abruptly changed ( $\mathrm{T}$. Li et al., 2015; W. J. Li et al., 2015).

In this study, a proxy based on solar radiation, $\mathrm{SO}_{2}$ concentration, $\mathrm{CS}$, and $\mathrm{RH}$ was used to roughly estimate the magnitude of sulfuric acid concentration in the atmosphere. In the calculations, the average sulfuric acid proxy concentration of all NPF days was $5.23 \times 10^{6} \mathrm{~cm}^{-3}$ during 06:00-09:00 LT, which could be comparable with $4.1 \times 10^{6} \mathrm{~cm}^{-3}$ in Beijing but much lower than $2.3 \times 10^{7}-$ $6.4 \times 10^{7} \mathrm{~cm}^{-3}$ in Shanghai and $6.6 \times 10^{7}-7.8 \times 10^{7} \mathrm{~cm}^{-3}$ in Nanjing (H. Wang et al., 2014; Wang et al., 2015; Xiao et al., 2015). Severely polluted sites generally correspond to elevated CS and thus require a higher concentration of precursors to initiate nucleation to some extent. This fact

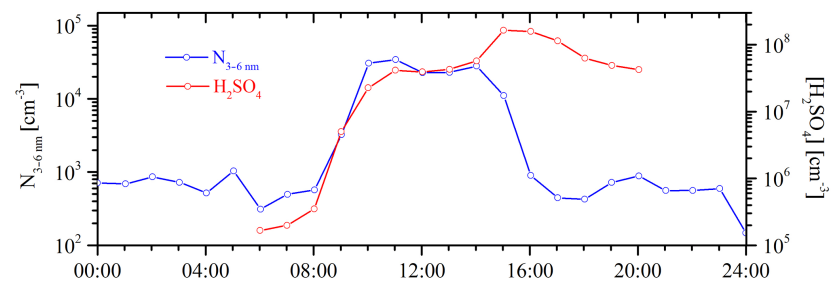

Figure 3. The particle number concentration of 3-6 nm $\left(N_{3}-6\right.$, blue) and sulfuric acid proxy concentration $\left(\left[\mathrm{H}_{2} \mathrm{SO}_{4}\right]\right.$, red) on 14 October 2014 fit a good relationship $\left(R^{2}=0.975\right)$ between $06: 00$ and 14:00 LT during the NPF event.

could be indirectly reflected through many oversea studies in which NPF events were observed at clean or moderately polluted sites in the presence of lower sulfuric acid concentration (Dal Maso et al., 2005; Boy et al., 2005). The lower initial sulfuric acid proxy concentration in this study could be partly explained by a relatively lower CS on Mt. Tai.

As the most critical nucleation precursor, sulfuric acid is associated with freshly nucleated particles. Further investigation in this study found that sulfuric acid proxy concentration showed the clear positive correlation with $N_{3-6}$ on many NPF days, consistent with earlier reports (Kulmala et al., 2006; Wang et al., 2011; Guo et al., 2012). The positive correlation was more evidence that sulfuric acid played the dominant role in NPF at the summit of Mt. Tai, as previously discussed. As an example, $N_{3-6}$ reflected the best relationship $\left(R^{2}=0.975\right)$ with sulfuric acid proxy concentration between 06:00 and 14:00 LT on the NPF day of 14 October 2014 (Fig. 3). After 14:00 LT, $\mathrm{SO}_{2}$ concentration increased sharply (a change from $2.6 \mathrm{ppb}$ at 14:00 LT to $19.1 \mathrm{ppb}$ at 15:00 LT), resulting in a lack of correlation between $\mathrm{SO}_{2}$ concentration and $N_{3-6}$ in the afternoon. In principle, the increase in sulfuric acid concentration should take place earlier than the in- 

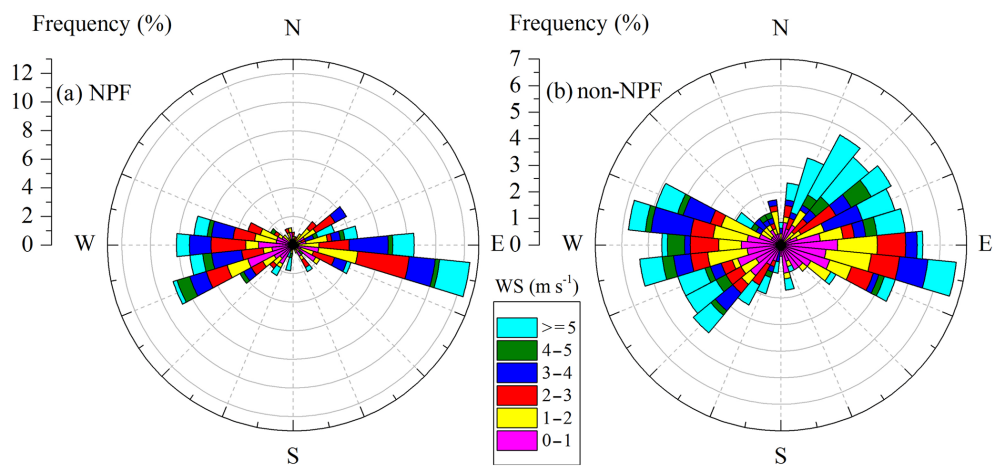

Figure 4. Wind rose plots of all NPF days (a) and non-NPF days (b) and wind speed and wind direction between 06:00 and 11:00 LT are included. The length of each spoke on the circle represents the probability of wind coming from a particular direction at a certain range of wind speed.

crease in $N_{3-6}$. However, there were some NPF days with zero or negative time delay in this study, such as on 14 October 2014 in Fig. 3. Wang et al. (2011) indicated that the preformed nucleation-mode particles and rapid particle growth might account for such zero or negative time delay.

Wind direction reflected the local situation for air mass, which could indirectly verify the competition between sinks and sources. Throughout the three campaigns, the dominant wind directions were easterly and westerly at $40-110$ and 220-300 ${ }^{\circ}$, respectively (Fig. 4). Compared with non-NPF days, wind direction on NPF days had narrower ranges in the east-southeasterly $\left(85-110^{\circ}\right)$ and west-southwesterly directions $\left(250-300^{\circ}\right)$, as shown in Fig. 4. The CS on Mt. Tai changed with wind direction, and the average CS in the wind directions between 40 and $110^{\circ}\left(2.0 \times 10^{-2} \mathrm{~s}^{-1}\right)$ was almost twice as high as that in the wind directions between 220 and $300^{\circ}\left(1.1 \times 10^{-2} \mathrm{~s}^{-1}\right)$. This indicated that air mass from the west of Mt. Tai was usually cleaner than that from the east. For the easterly wind, it was noted that the CS was a relatively small value when wind came from the east-southeast direction, partly explaining the frequent occurrence of NPF events in this particular direction. $\mathrm{SO}_{2}$ concentrations were almost evenly distributed with wind direction in this study, except for the west-southwest direction, which corresponded to an elevated $\mathrm{SO}_{2}$ concentration of $4.3 \mathrm{ppb}$ on average. In contrast, the average $\mathrm{SO}_{2}$ concentration was only $2.0 \mathrm{ppb}$ for the adjacent wind directions between 220 and $350^{\circ}$. This suggested that potential sources in the west-southwest direction contributed to a greater likelihood of NPF.

$\mathrm{O}_{3}$ can directly react with volatile organic compounds or indirectly affect sulfuric acid formation via hydroxyl and hydroperoxy radicals (Berndt et al., 2010; Gómez Martín et al., 2013; Sorribas et al., 2015; Guo et al., 2012), and thus $\mathrm{O}_{3}$ in the atmosphere may theoretically play a role in NPF. Previous research showed that elevated $\mathrm{O}_{3}$ concentration was beneficial to the occurrence of NPF events (An et al., 2015; Guo et al., 2012; Zhang et al., 2016; Huang et al., 2016), and our results did not directly show a similar phenomenon.
The average $\mathrm{O}_{3}$ concentrations on NPF days and non-NPF days were 40 and $47 \mathrm{ppb}$, respectively, and hourly average $\mathrm{O}_{3}$ concentrations on NPF days were always lower than those on non-NPF days in Fig. 2b. The increasing rate of $\mathrm{O}_{3}$ concentration on NPF days was significantly faster than that on non-NPF days after sunrise, implying that NPF did prefer abundant $\mathrm{O}_{3}$ conditions. Conversely, the lower $\mathrm{O}_{3}$ concentration on NPF days also indicated that $\mathrm{O}_{3}$ was not a key factor for NPF on Mt. Tai. Previous studies reported that there was a $\mathrm{NO}_{x}$ turnaround value of $10-15 \mathrm{ppb}$ for formation of $\mathrm{O}_{3}$, and $\mathrm{O}_{3}$ production appeared to decrease as $\mathrm{NO}_{x}$ did when $\mathrm{NO}_{x}$ concentration exceeded the turnaround value (Lei et al., 2004). The average concentrations of $\mathrm{NO}+\mathrm{NO}_{2}$ on NPF days and non-NPF days were 21 and $20 \mathrm{ppb}$ on Mt. Tai. The high level of $\mathrm{NO}_{x}$ concentration inversely contributed to $\mathrm{O}_{3}$ formation to some extent, which was partially responsible for decreased $\mathrm{O}_{3}$ concentration on NPF days.

In Fig. 2b, the diurnal variations in $\mathrm{O}_{3}$ concentration at the summit of Mt. Tai had two prominent features - a small trough in the early morning resulting from dry deposition and a broad peak in the afternoon due to formation by solar radiation. As Sun et al. (2016) reported, $\mathrm{O}_{3}$ concentration between 02:00 and 05:00 LT reflected the regional baseline of $\mathrm{O}_{3}$. In this study, the average regional baseline of $\mathrm{O}_{3}$ was $42 \mathrm{ppb}$, which is a relatively high level. This result should be related to residual $\mathrm{O}_{3}$ produced the preceding afternoon in the boundary layer.

\subsection{Meteorological conditions}

Favorable meteorological conditions can promote the occurrence of NPF events, especially when the precursor concentrations are insufficient in the atmosphere (Song et al., 2010). In this study, approximately $90 \%$ of NPF events occurred during clear or partially cloudy daytime. As discussed earlier in Sect. 3.1, NPF events initiated at the same time as rapidly increasing solar radiation, suggesting the association between solar radiation and NPF. 

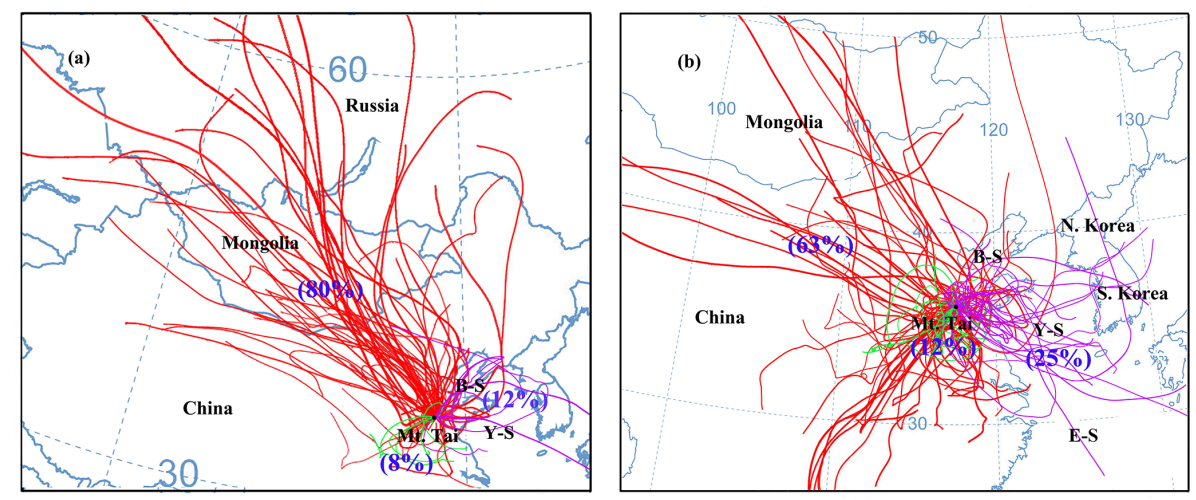

Figure 5. Air mass backward trajectories for $72 \mathrm{~h}$ at 06:00 LT at $1535 \mathrm{~m}$ a.s.l. on all NPF days (a) and non-NPF days (b), and the continental air mass, local air mass, and maritime air mass are represented in red, green, and magenta, respectively. B-S: Bohai Sea; Y-S: Yellow Sea; E-S: East China Sea.

The air temperature of all NPF days varied from -11.8 to $22.1^{\circ} \mathrm{C}$ in this study. The daily temperature profiles were characterized by the expected cosine form of the curve, and daily temperature generally oscillated less than $10^{\circ} \mathrm{C}$ within a day. Temperature at the summit of Mt. Tai exhibited a clear seasonal behavior. As observed in Fig. 2c, the hourly average temperatures on non-NPF days $\left(10.7 \pm 1.1^{\circ} \mathrm{C}\right)$ were always higher than those on NPF days $\left(7.0 \pm 1.8^{\circ} \mathrm{C}\right)$, indicating that NPF at the summit of Mt. Tai favored the relatively low air temperature. This result was in good agreement with many previous observations at Tai Mo Shan (Guo et al., 2012), Mt. Huang (Zhang et al., 2016), and Puy de Dôme in France (Rose et al., 2015), which all reported the correlation between lower temperature and NPF events. In Guo et al. (2012), this explained favorable lower temperature enhancing the bind between sulfuric acid and water molecules. Li et al. (2017) also indicated that the strength $(r)$ of lactic acid increased with decreasing temperature based on molecular-scale study of interaction between lactic acid and nucleation precursors. In addition, the enhancement of NPF events at a lower temperature was partly attributed to atmospheric vertical convection and enhanced matter transport.

The RH on NPF days ranged from 22 to $95 \%$, and diurnal variation in RH was inversely correlated with solar radiation. The hourly average RH on NPF days $(63 \pm 5 \%)$ was always much lower than the corresponding value on nonNPF days ( $88 \pm 2 \%$ ), and the maximum difference between two curves in Fig. 2d was as high as $30 \%$ at noon. An anticorrelation between NPF and RH could be identified at the summit of Mt. Tai, which was in agreement with results in Beijing, Nanjing, Hong Kong, and Mt. Huang (An et al., 2015; D. W. Wang et al., 2014; Shen et al., 2016; Zhang et al., 2016; Guo et al., 2012). The actual role of RH on NPF is still controversial. Hamed et al. (2011) indicated that RH affected the source of NPF via decreasing solar radiation under high RH conditions. In contrast, simultaneous increasing CS under high RH conditions was also suggested as an explana- tion for the negative effect of RH (Hamed et al., 2011; Guo et al., 2012). Li et al. (2017) reported that the strength $(r)$ of lactic acid in NPF events revealed sensitivity to RH and increased with decreasing RH, which was possibly associated with hydration ability of sulfuric acid-base clusters.

\subsection{Long-range air mass transport}

To characterize the influence of long-range air mass transport on NPF at the summit of Mt. Tai, air mass backward trajectories for $72 \mathrm{~h}$ at $06: 00 \mathrm{LT}$ at $1535 \mathrm{~m}$ a.s.l. were simulated by using the HYSPLIT model developed by the NOAA Air Resources Laboratory. Figure 5a illustrates the air mass backward trajectories of all NPF days, and Fig. 5b shows all non-NPF days.

Based on transport range and distance, the air mass backward trajectories were classified into three categories in Fig. 5: continental air mass (red), local air mass (green), and maritime air mass (magenta). The majority of transport pathways on NPF days were continental air mass, which accounted for $80 \%$ of total air masses. The continental air mass on NPF days mainly came from northwest of the observation site and largely originated from Siberia passing over a long distance across Mongolia, Inner Mongolia, Shanxi Province, Hebei Province, and Beijing. The local and maritime backward trajectories on NPF days accounted for 8 and $12 \%$ of total trajectories, respectively. The local air mass was mainly from surrounding cities such as Jinan, Nanjing, and Zhengzhou with shorter routes, whereas the maritime air mass originated over the Bohai Sea, Yellow Sea, and East China Sea.

The ratios of continental air mass, local air mass, and maritime air mass on non-NPF days were 63,12 , and $25 \%$, respectively. Overall, the local air mass accounted for the minimum percentage on both NPF and non-NPF days. It was noted that there was a significantly lower ratio of maritime air mass and shorter routes over ocean areas on NPF days in Fig. 5a. The phenomena were in line with the study of Peng 


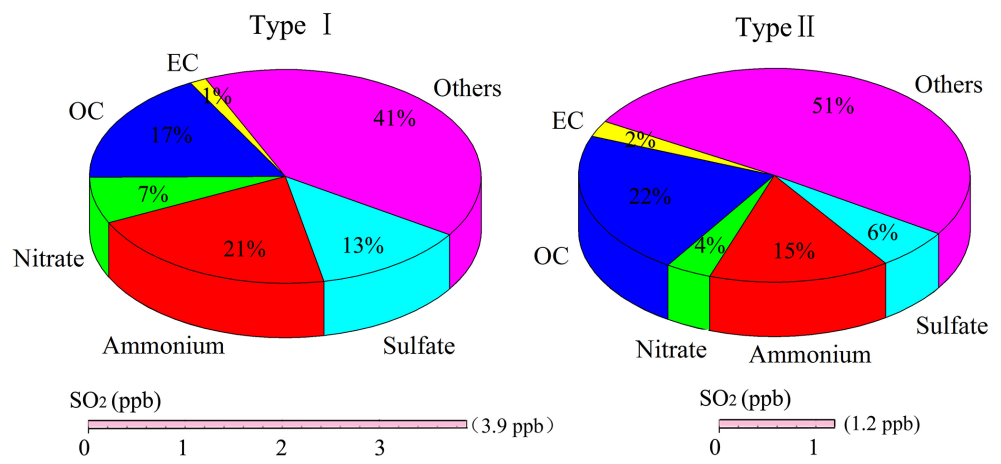

Figure 6. The average chemical composition of $\mathrm{PM}_{2.5}$ and $\mathrm{SO}_{2}$ concentration in a more polluted continental air mass (Type I) and a relatively cleaner continental air mass (Type II) on NPF days.

et al. (2014) in which non-NPF events were observed when the air mass came from the clean ocean side at three coastal sites. The reason for this result was probably that the maritime air mass could not provide enough precursors for NPF.

As mentioned above, the continental air mass dominated throughout observations. According to its transport region, a more polluted continental air mass (Type I) and a relatively cleaner continental air mass (Type II) were denoted in this study. The air mass of Type I passed through the heavily polluted areas of Beijing, Hebei Province, Shanxi Province, Henan Province, and Shaanxi Province before reaching the observation site, which probably carried a substantial fraction of extra matters. The air mass of Type II was either from southern China or transported over the Bohai Sea and Yellow Sea, and thus it represented a relatively cleaner air mass. In this study, four-fifths of continental air masses on NPF days were Type I, whereas Type I only accounted for two-fifths on non-NPF days. The significant difference implied that Type I air masses passing through heavily polluted areas might be favored for NPF.

In order to further verify the speculation that Type I air mass was favorable for NPF, Fig. 6 illustrates the average chemical composition of $\mathrm{PM}_{2.5}$ and $\mathrm{SO}_{2}$ concentration in Type I and Type II on NPF days. The average mass concentrations of $\mathrm{PM}_{2.5}$ in Type I and Type II were 33 and $23 \mu \mathrm{g} \mathrm{m}^{-3}$, and Type I air mass was obviously more polluted than Type II. It was noted that a prominent increase in $\mathrm{SO}_{2}$ concentration was found in Type I, compared with the average $\mathrm{SO}_{2}$ concentration between 3.9 and $1.2 \mathrm{ppb}$. Higher $\mathrm{SO}_{2}$ concentration suggested that sulfuric acid participated in NPF and played an important role in it, which could also be reflected by the largest enhancement mixing ratio of sulfate in $\mathrm{PM}_{2.5}$ in Type I. In addition, the significantly elevated mixing ratios of ammonium and nitrate were found in Type I, suggesting that these polluted areas might be N-rich and potential ammonia also promoted efficient NPF in Type I.

Long-range air mass transport reflects a regional picture before nucleation; thus, it is of great importance for NPF. An NPF event on 11 November 2014 was picked as a case study to further explore the influence of long-range air mass transport. The time series of particle size distribution, trace gases, and chemical composition and mass concentration of $\mathrm{PM}_{2.5}$ on this day are illustrated in Fig. 7.

In the early morning on 11 November 2014, the average concentrations of $\mathrm{SO}_{2}$ and $\mathrm{PM}_{2.5}$ were $1.7 \mathrm{ppb}$ and $90 \mu \mathrm{g} \mathrm{m}^{-3}$, respectively. A low level of $\mathrm{SO}_{2}$ concentration and extremely high level of $\mathrm{PM}_{2.5}$ concentration made atmospheric nucleation almost impossible. However, an NPF event was observed around noon, and the observed start time showed an obvious time delay compared with the general start time of 08:00-11:00 LT in Sect. 3.1. In Fig. 7, the simultaneous clear increase in $\mathrm{SO}_{2}$ concentration, decrease in $\mathrm{PM}_{2.5}$ concentration, and change in chemical composition of $\mathrm{PM}_{2.5}$ were found at about 10:00 LT. The observation site of Mt. Tai is located on the mountaintop without any stationary source nearby, and these abrupt changes may suggest that there was another air mass transported to the site contributing to this unexpected NPF event. During 06:00 09:00 LT, the average mass concentrations of sulfate, ammonium, nitrate, $\mathrm{OC}$, and $\mathrm{EC}$ in $\mathrm{PM}_{2.5}$ were 4.1, 4.6, 4.1, 7.6 and $0.7 \mu \mathrm{g} \mathrm{m}^{-3}$, respectively. In contrast, their average concentrations shifted to $13.1,11.2,11.1,10.0$, and $0.2 \mu \mathrm{g} \mathrm{m}^{-3}$ during 11:00-18:00 LT. The mixing ratio of sulfate in $\mathrm{PM}_{2.5}$ increased significantly before and after 10:00 LT, suggesting that the new transport air mass was S-rich. Dual effects of elevated precursor (sulfuric acid) concentration and decreased preexisting particle loadings were responsible for this NPF event.

In order to verify the above speculation, air mass backward trajectories for $72 \mathrm{~h}$ at $1535 \mathrm{~m}$ a.s.1. at 14:00, 12:00, 10:00, 08:00, and 06:00 LT on 11 November 2014 are shown in Fig. 8. Figure 8 illustrates that the origin of transport air mass shifted from eastern China (Jiangsu and Anhui provinces, lines $\mathrm{A}$ and $\mathrm{B}$ ) to western China (lines $\mathrm{C}-\mathrm{E}$ ) at about 10:00 LT, which was in agreement with the earlier analysis in Fig. 7. The latter air mass backward trajectories (line $\mathrm{C}-\mathrm{E}$ ) passed through the heavily polluted areas, such as Shanxi and Shaanxi Provinces, before reaching the site of 

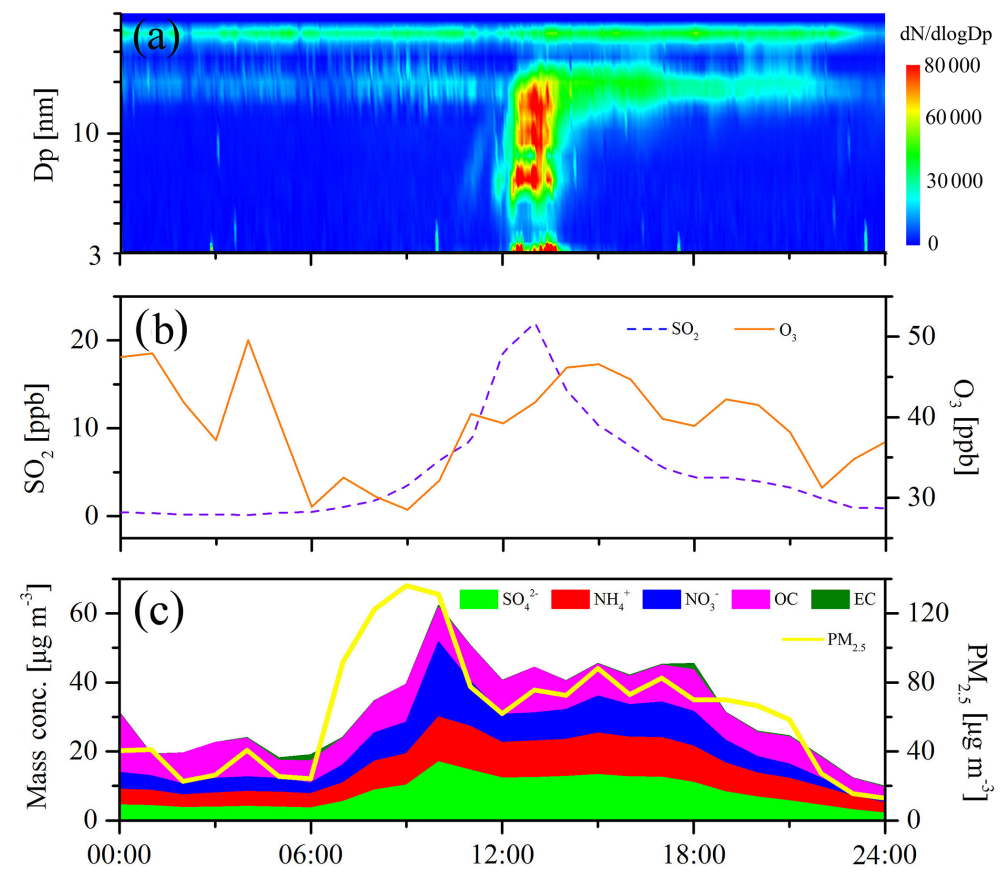

Figure 7. Time series of particle size distribution, trace gases, and chemical composition and mass concentration of $\mathrm{PM}_{2.5}$ on $11 \mathrm{Novem}^{-}$ ber 2014 .

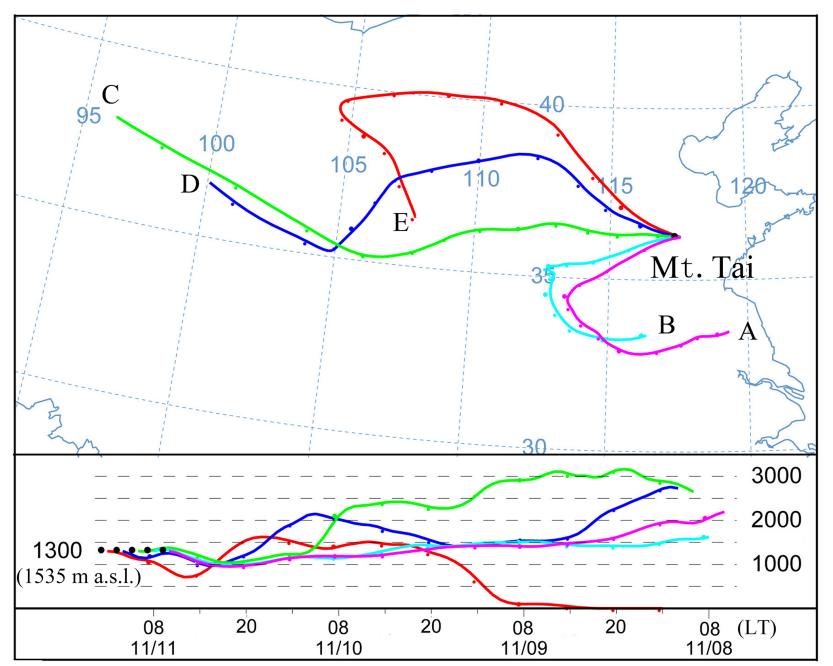

Figure 8. Air mass backward trajectories for $72 \mathrm{~h}$ at $1535 \mathrm{~m}$ a.s.l. at 06:00 (A), 08:00 (B), 10:00 (C), 12:00 (D), and 14:00 LT (E) on 11 November 2014.

Mt. Tai. Those polluted areas were rich in $\mathrm{SO}_{2}$, leading to enhanced precursors for NPF.

\subsection{Potential governing factors for NPF}

NPF at the summit of Mt. Tai revealed an obvious seasonal distribution. The occurrence frequency in summertime was strongly associated with atmospheric humidity, and the rainy and foggy conditions were a critical limiting factor for NPF in summertime. The nucleation-mode particle concentrations were more fluctuant in summertime than in autumn and winter, which was possibly caused by heterogeneity of precursors. In autumn and winter, the effect of meteorological conditions was not so overwhelming, and precursor species and particle sinks played the key roles for NPF.

Earlier discussion of $\mathrm{SO}_{2}$ in this study indicated that sulfuric acid played the dominant role in NPF at the summit of Mt. Tai. A large formation rate was observed in this study, but it could not be explained by only sulfuric acid because of insufficient sulfuric acid concentration in the atmosphere. Zhang et al. (2004) showed that the organic acid-sulfuric acid system had a reduced nucleation barrier, and nucleation could be promoted several times in the presence of a subparts-per-billion level of organics. Mt. Tai in this study has a high percentage of forest-covered lands and thus abundant biogenic organics are theoretically released in warm seasons. Apart from sulfuric acid, biogenic organics most probably acted as the important precursors of NPF on Mt. Tai in warm seasons. In cold seasons, the release of biogenic organics might be reduced, but emissions of anthropogenic volatile organic compounds and $\mathrm{SO}_{2}$ would be enhanced because of domestic heating in the region, contributing to NPF in winter.

\section{Conclusions}

For NPF, although a few observational results have been reported in China, to date very few studies have conducted 
a comprehensive analysis of favorable conditions that gave rise to NPF at mountaintop sites, not to mention investigating characteristics of NPF measured with improved instruments. A comprehensive investigation of NPF was conducted at the summit of Mt. Tai (1534 m a.s.1.), eastern China, from 25 July to 24 August 2014 (Phase I), 21 September to 9 December 2014 (Phase II), and 16 June to 7 August 2015 (Phase III), mainly using an NAIS instrument that could detect particles at smaller sizes.

During the 164 days, 66 NPF events were identified, giving an occurrence frequency of $40 \%$. Approximately $95 \%$ of NPF events initiated at 08:00-11:00 LT coincided with many previous reports in China. The $J_{3}, J_{3-20}$, and growth rates were in the range of $0.82-25.04 \mathrm{~cm}^{-3} \mathrm{~s}^{-1}$, $1.10-57.43 \mathrm{~cm}^{-3} \mathrm{~s}^{-1}$, and $0.58-7.76 \mathrm{~nm} \mathrm{~h}^{-1}$, respectively. In comparison with other studies in China, the formation rate at the summit of Mt. Tai was relatively large, which was partially attributable to a lower CS on Mt. Tai. In contrast, the lower growth rate suggested that precursors for particle growth were probably insufficient.

On average, the $\mathrm{CS}, \mathrm{O}_{3}$ concentration, $T$, and $\mathrm{RH}$ were lower, whereas $\mathrm{SO}_{2}$ concentration was higher on NPF days than that on non-NPF days. The CS on Mt. Tai was significantly lower compared with many other locations in China, and lower CS was one of the critical factors for NPF. East-southeasterly $\left(85-110^{\circ}\right)$ and west-southwesterly winds (250-300 ${ }^{\circ}$ dominated on NPF days, and a relatively lower $\mathrm{CS}$ in the east-southeast and higher $\mathrm{SO}_{2}$ concentration in the west-southwest were partially responsible for NPF. Elevated $\mathrm{O}_{3}$ concentration was favorable for $\mathrm{NPF}$, but $\mathrm{O}_{3}$ was not a governing factor for NPF on Mt. Tai. The high level of $\mathrm{NO}_{x}$ concentration on Mt. Tai was adverse to $\mathrm{O}_{3}$ formation, probably leading to the decreased $\mathrm{O}_{3}$ concentration on NPF days. Lower $T$ and lower RH were expectedly observed on NPF days in this study, which were in good agreement with previous results at other sites.

Three categories of backward air masses were classified on Mt. Tai, and they were continental air mass, local air mass, and maritime air mass. The continental air mass was the majority on both NPF and non-NPF days, and it was divided into Type I (more polluted continental air mass) and Type II (relatively cleaner continental air mass). An in-depth analysis showed that Type I air mass was in favor of NPF because higher $\mathrm{SO}_{2}$ concentration and potential ammonia were carried with it.

Sulfuric acid was identified as a dominant precursor of NPF at the summit of Mt. Tai, but its concentration was not sufficient to explain the highly large formation rate in this study. Abundant forest-covered Mt. Tai implied that considerable biogenic organics might be released in warm seasons and participate in NPF. In addition, increasing anthropogenic volatile organic compounds and $\mathrm{SO}_{2}$ in the region could promote NPF in cold seasons. Further measurement of organics is still needed to explore what kind of organics participate in NPF.
Data availability. The data of this paper are available upon request (jmchen@fudan.edu.cn; lvganglinsdu@163.com).

Competing interests. The authors declare that they have no conflict of interest.

Special issue statement. This article is part of the special issue "Regional transport and transformation of air pollution in eastern China". It is not associated with a conference.

Acknowledgements. This work was supported by the National Natural Science Foundation of China (no. 41375126), Mount Tai Scholar Grand (ts20120552), Cyrus Tang Foundation (no. CTFFD2014001), Ministry of Science and Technology of China (SQ2016ZY01002231, 2014BAC22B01), and Marie SkłodowskaCurie actions (H2020-MSCA-RISE-2015-690958).

Edited by: Renyi Zhang

Reviewed by: two anonymous referees

\section{References}

Allan, J. D., Williams, P. I., Najera, J., Whitehead, J. D., Flynn, M. J., Taylor, J. W., Liu, D., Darbyshire, E., Carpenter, L. J., Chance, R., Andrews, S. J., Hackenberg, S. C., and McFiggans, G.: Iodine observed in new particle formation events in the Arctic atmosphere during ACCACIA, Atmos. Chem. Phys., 15, 55995609, https://doi.org/10.5194/acp-15-5599-2015, 2015.

An, J., Wang, H., Shen, L., Zhu, B., Zou, J., Gao, J., and Kang, H.: Characteristics of new particle formation events in Nanjing, China: Effect of water-soluble ions, Atmos. Environ., 108, 3240, https://doi.org/10.1016/j.atmosenv.2015.01.038, 2015.

Berndt, T., Stratmann, F., Sipilä, M., Vanhanen, J., Petäjä, T., Mikkilä, J., Grüner, A., Spindler, G., Lee Mauldin Iii, R., Curtius, J., Kulmala, M., and Heintzenberg, J.: Laboratory study on new particle formation from the reaction $\mathrm{OH}+\mathrm{SO}_{2}$ : influence of experimental conditions, $\mathrm{H}_{2} \mathrm{O}$ vapour, $\mathrm{NH}_{3}$ and the amine tert-butylamine on the overall process, Atmos. Chem. Phys., 10, 7101-7116, https://doi.org/10.5194/acp-10-7101-2010, 2010.

Boy, M., Kulmala, M., Ruuskanen, T. M., Pihlatie, M., Reissell, A., Aalto, P. P., Keronen, P., Dal Maso, M., Hellen, H., Hakola, H., Jansson, R., Hanke, M., and Arnold, F.: Sulphuric acid closure and contribution to nucleation mode particle growth, Atmos. Chem. Phys., 5, 863-878, https://doi.org/10.5194/acp-5863-2005, 2005.

Butt, E. W., Rap, A., Schmidt, A., Scott, C. E., Pringle, K. J., Reddington, C. L., Richards, N. A. D., Woodhouse, M. T., RamirezVillegas, J., Yang, H., Vakkari, V., Stone, E. A., Rupakheti, M., S. Praveen, P., van Zyl, G., Beukes, J., Josipovic, M., Mitchell, E. J. S., Sallu, S. M., Forster, P. M., and Spracklen, D. V.: The impact of residential combustion emissions on atmospheric aerosol, human health, and climate, Atmos. Chem. Phys., 16, 873-905, https://doi.org/10.5194/acp-16-873-2016, 2016.

Cai, R., Yang, D., Fu, Y., Wang, X., Li, X., Ma, Y., Hao, J., Zheng, J., and Jiang, J.: Aerosol surface area concentration: a govern- 
ing factor in new particle formation in Beijing, Atmos. Chem. Phys., 17, 12327-12340, https://doi.org/10.5194/acp-17-123272017, 2017.

Chiharu, N., Kazuo, O., Mizuka, K., Katsuji, M., and Yasunobu, I.: Nucleation mode particles in upslope valley winds at Mount Norikura, Japan: Implications for the vertical extent of new particle formation events in the lower troposphere, J. Geophys. Res., 113, D06202, https://doi.org/10.1029/2007jd009302, 2008.

Dal Maso, M., Kulmala, M., Lehtinen, K. E. J., Mäkelä, J. M., Aalto, P., and O'Dowd, D.: Condensation and coagulation sinks and formation of nucleation mode particles in coastal and boreal forest boundary layers, J. Geophys. Res., 107, 8097, https://doi.org/10.1029/2001JD001053, 2002.

Dal Maso, M., Kulmala, M., Riipinen, I., Wagner, R., Hussein, T., Aalto, P. P., and Lehtinen, K. E. J.: Formation and growth of fresh atmospheric aerosols: Eight Years of Aerosol Size Distribution Data from SMEAR II, Hyytiälä, Finland, Boreal Environ. Res., 10, 323-336, 2005.

Du, W., Sun, Y. L., Xu, Y. S., Jiang, Q., Wang, Q. Q., Yang, W., Wang, F., Bai, Z. P., Zhao, X. D., and Yang, Y. C.: Chemical characterization of submicron aerosol and particle growth events at a national background site (3295 ma.s.1.) in the Tibetan Plateau, Atmos. Chem. Phys., 15, 10811-10824, https://doi.org/10.5194/acp-15-10811-2015, 2015.

Gao, J., Wang, T., Zhou, X., Wu, W., and Wang, W.: Measurement of aerosol number size distributions in the Yangtze River delta in China: Formation and growth of particles under polluted conditions, Atmos. Environ., 43, 829-836, https://doi.org/10.1016/j.atmosenv.2008.10.046, 2009.

Gao, J., Chai, F., Wang, T., and Wang, W.: Particle number size distribution and new particle formation (NPF) in Lanzhou, Western China, Particuology, 9, 611-618, https://doi.org/10.1016/j.partic.2011.06.008, 2011.

Gao, J., Chai, F., Wang, T., Wang, S., and Wang, W.: Particle number size distribution and new particle formation: New characteristics during the special pollution control period in Beijing, J. Environ. Sci., 24, 14-21, https://doi.org/10.1016/s10010742(11)60725-0, 2012.

Gómez Martín, J. C., Gálvez, O., Baeza-Romero, M. T., Ingham, T., Plane, J. M., and Blitz, M. A.: On the mechanism of iodine oxide particle formation, Phys. Chem. Chem. Phys., 15, 15612-15622, https://doi.org/10.1039/c3cp51217g, 2013.

Gong, Y., Hu, M., Cheng, Y., Su, H., Yue, D., Liu, F., Wiedensohler, A., Wang, Z., Kalesse, H., and Liu, S.: Competition of coagulation sink and source rate: New particle formation in the Pearl River Delta of China, Atmos. Environ., 44, 3278-3285, https://doi.org/10.1016/j.atmosenv.2010.05.049, 2010.

Guo, H., Wang, D. W., Cheung, K., Ling, Z. H., Chan, C. K., and Yao, X. H.: Observation of aerosol size distribution and new particle formation at a mountain site in subtropical Hong Kong, Atmos. Chem. Phys., 12, 9923-9939, https://doi.org/10.5194/acp12-9923-2012, 2012.

Guo, S., Hu, M., Zamora, M. L., Peng, J., Shang, D., Zheng, J., Du, Z., Wu, Z., Shao, M., Zeng, L., Molina, M. J., and Zhang, R.: Elucidating severe urban haze formation in China, P. Natl. Acad. Sci. USA, 111, 17373-17378, https://doi.org/10.1073/pnas.1419604111, 2014.

Hallar, A. G., Lowenthal, D. H., Chirokova, G., Borys, R. D., and Wiedinmyer, C.: Persistent daily new particle formation at a mountain-top location, Atmos. Environ., 45, 4111-4115, https://doi.org/10.1016/j.atmosenv.2011.04.044, 2011.

Hamed, A., Korhonen, H., Sihto, S.-L., Joutsensaari, J., Järvinen, H., Petäjä, T., Arnold, F., Nieminen, T., Kulmala, M., Smith, J. N., Lehtinen, K. E. J., and Laaksonen, A.: The role of relative humidity in continental new particle formation, J. Geophys. Res., 116, 909-926, https://doi.org/10.1029/2010jd014186, 2011.

Han, S.: Effect of Aerosols on Visibility and Radiation in Spring 2009 in Tianjin, China, Aerosol Air Qual. Res., 12, 211 217, https://doi.org/10.4209/aaqr.2011.05.0073, 2012.

Hao, J., Yin, Y., Li, X., Yuan, L., and Xiao, H.: Observations of Nucleation Mode Particles Formation and Growth on Mount Huang, China, Procedia Engineering, 102, 1167-1176, https://doi.org/10.1016/j.proeng.2015.01.242, 2015.

Herrmann, E., Ding, A. J., Kerminen, V. M., Petäjä, T., Yang, X. Q., Sun, J. N., Qi, X. M., Manninen, H., Hakala, J., Nieminen, T., Aalto, P. P., Kulmala, M., and Fu, C. B.: Aerosols and nucleation in eastern China: first insights from the new SORPES-NJU station, Atmos. Chem. Phys., 14, 2169-2183, https://doi.org/10.5194/acp-14-2169-2014, 2014.

Hu, M., Shang, D., Guo, S., and Wu, Z.: Mechanism of New Particle Formation and Growth as well as Environmental Effects under Complex Air Pollution in China, Acta Chim. Sin., 74, 385-391, https://doi.org/10.6023/a16020105, 2016.

Huang, X., Zhou, L., Ding, A., Qi, X., Nie, W., Wang, M., Chi, X., Petäjä, T., Kerminen, V.-M., Roldin, P., Rusanen, A., Kulmala, M., and Boy, M.: Comprehensive modelling study on observed new particle formation at the SORPES station in Nanjing, China, Atmos. Chem. Phys., 16, 2477-2492, https://doi.org/10.5194/acp-16-2477-2016, 2016.

Jayaratne, R., Pushpawela, B., He, C., Li, H., Gao, J., Chai, F., and Morawska, L.: Observations of particles at their formation sizes in Beijing, China, Atmos. Chem. Phys., 17, 8825-8835, https://doi.org/10.5194/acp-17-8825-2017, 2017.

Kanawade, V. P., Shika, S., Pöhlker, C., Rose, D., Suman, M. N. S., Gadhavi, H., Kumar, A., Nagendra, S. M. S., Ravikrishna, R., Yu, H., Sahu, L. K., Jayaraman, A., Andreae, M. O., Pöschl, U., and Gunthe, S. S.: Infrequent occurrence of new particle formation at a semi-rural location, Gadanki, in tropical Southern India, Atmos. Environ., 94, 264-273, https://doi.org/10.1016/j.atmosenv.2014.05.046, 2014.

Kazil, J., Stier, P., Zhang, K., Quaas, J., Kinne, S., O’Donnell, D., Rast, S., Esch, M., Ferrachat, S., Lohmann, U., and Feichter, J.: Aerosol nucleation and its role for clouds and Earth's radiative forcing in the aerosol-climate model ECHAM5-HAM, Atmos. Chem. Phys., 10, 10733-10752, https://doi.org/10.5194/acp-1010733-2010, 2010.

Kuang, C., Riipinen, I., Sihto, S. L., Kulmala, M., McCormick, A. V., and McMurry, P. H.: An improved criterion for new particle formation in diverse atmospheric environments, Atmos. Chem. Phys., 10, 8469-8480, https://doi.org/10.5194/acp-108469-2010, 2010.

Kulmala, M., Dal Maso, M., Mäkelä, M., Pirjola, L., Väkevä, M., Aalto, P., Miikkulainen, P., and Hämeri, K.: On the formation, growth and composition of nucleation mode particles, Tellus B, 53, 479-490, https://doi.org/10.1034/j.16000889.2001.d01-33.x, 2001.

Kulmala, M., Vehkamäki, H., Petäjä, T., Dal Maso, M., Lauri, A., Kerminen, V. M., Birmili, W., and McMurry, P. H.: 
Formation and growth rates of ultrafine atmospheric particles: a review of observations, J. Aerosol Sci., 35, 143-176, https://doi.org/10.1016/j.jaerosci.2003.10.003, 2004.

Kulmala, M., Lehtinen, K. E. J., and Laaksonen, A.: Cluster activation theory as an explanation of the linear dependence between formation rate of $3 \mathrm{~nm}$ particles and sulphuric acid concentration, Atmos. Chem. Phys., 6, 787-793, https://doi.org/10.5194/acp-6787-2006, 2006.

Kulmala, M., Petäjä, T., Nieminen, T., Sipila, M., Manninen, H. E., Lehtipalo, K., Dal Maso, M., Aalto, P. P., Junninen, H., Paasonen, P., Riipinen, I., Lehtinen, K. E., Laaksonen, A., and Kerminen, V. M.: Measurement of the nucleation of atmospheric aerosol particles, Nat. Protoc., 7, 1651-1667, https://doi.org/10.1038/nprot.2012.091, 2012.

Kulmala, M., Petäjä, T., Kerminen, V. M., Kujansuu, J., Ruuskanen, T., Ding, A. J., Nie, W., Hu, M., Wang, Z. B., Wu, Z. J., Wang, L., and Worsnop, D. R.: On secondary new particle formation in China, Front. Environ. Sci. Eng., 10, 08, https://doi.org/10.1007/s11783-016-0850-1, 2016.

Lei, W., Zhang, R., Tie, X., and Hess, P.: Chemical characterization of ozone formation in the Houston-Galveston area: A chemical transport model study, J. Geophys. Res., 109, D12301, https://doi.org/10.1029/2003jd004219, 2004.

Li, H., Kupiainen-Määttä, O., Zhang, H., Zhang, X., and Ge, M.: A molecular-scale study on the role of lactic acid in new particle formation: Influence of relative humidity and temperature, Atmos. Environ., 166, 479-487, https://doi.org/10.1016/j.atmosenv.2017.07.039, 2017.

Li, T., Wang, Y., Li, W. J., Chen, J. M., Wang, T., and Wang, W. X.: Concentrations and solubility of trace elements in fine particles at a mountain site, southern China: regional sources and cloud processing, Atmos. Chem. Phys., 15, 8987-9002, https://doi.org/10.5194/acp-15-8987-2015, 2015.

Li, W. J., Zhang, D. Z., Shao, L. Y., Zhou, S. Z., and Wang, W. $X$. Individual particle analysis of aerosols collected under haze and non-haze conditions at a high-elevation mountain site in the North China plain, Atmos. Chem. Phys., 11, 11733-11744, https://doi.org/10.5194/acp-11-11733-2011, 2011.

Li, W. J., Chen, S. R., Xu, Y. S., Guo, X. C., Sun, Y. L., Yang, X. Y., Wang, Z. F., Zhao, X. D., Chen, J. M., and Wang, W. $\mathrm{X}$.: Mixing state and sources of submicron regional background aerosols in the northern Qinghai-Tibet Plateau and the influence of biomass burning, Atmos. Chem. Phys., 15, 13365-13376, https://doi.org/10.5194/acp-15-13365-2015, 2015.

Liu, S., Hu, M., Wu, Z., Wehner, B., Wiedensohler, A., and Cheng, Y.: Aerosol number size distribution and new particle formation at a rural/coastal site in Pearl River Delta (PRD) of China, Atmos. Environ., 42, 6275-6283, https://doi.org/10.1016/j.atmosenv.2008.01.063, 2008.

Liu, X. H., Zhu, Y. J., Zheng, M., Gao, H. W., and Yao, X. H.: Production and growth of new particles during two cruise campaigns in the marginal seas of China, Atmos. Chem. Phys., 14, 7941-7951, https://doi.org/10.5194/acp-14-7941-2014, 2014.

Manninen, H. E., Nieminen, T., Asmi, E., Gagné, S., Häkkinen, S., Lehtipalo, K., Aalto, P., Vana, M., Mirme, A., Mirme, S., Hõrrak, U., Plass-Dülmer, C., Stange, G., Kiss, G., Hoffer, A., Törô, N., Moerman, M., Henzing, B., de Leeuw, G., Brinkenberg, M., Kouvarakis, G. N., Bougiatioti, A., Mihalopoulos, N., O'Dowd, C., Ceburnis, D., Arneth, A., Svenningsson, B., Swi- etlicki, E., Tarozzi, L., Decesari, S., Facchini, M. C., Birmili, W., Sonntag, A., Wiedensohler, A., Boulon, J., Sellegri, K., Laj, P., Gysel, M., Bukowiecki, N., Weingartner, E., Wehrle, G., Laaksonen, A., Hamed, A., Joutsensaari, J., Petäjä, T., Kerminen, V. M., and Kulmala, M.: EUCAARI ion spectrometer measurements at 12 European sites - analysis of new particle formation events, Atmos. Chem. Phys., 10, 7907-7927, https://doi.org/10.5194/acp10-7907-2010, 2010.

Mikkonen, S., Romakkaniemi, S., Smith, J. N., Korhonen, H., Petäjä, T., Plass-Duelmer, C., Boy, M., McMurry, P. H., Lehtinen, K. E. J., Joutsensaari, J., Hamed, A., Mauldin Iii, R. L., Birmili, W., Spindler, G., Arnold, F., Kulmala, M., and Laaksonen, A.: A statistical proxy for sulphuric acid concentration, Atmos. Chem. Phys., 11, 11319-11334, https://doi.org/10.5194/acp-1111319-2011, 2011.

Peng, J. F., Hu, M., Wang, Z. B., Huang, X. F., Kumar, P., Wu, Z. J., Guo, S., Yue, D. L., Shang, D. J., Zheng, Z., and He, L. Y.: Submicron aerosols at thirteen diversified sites in China: size distribution, new particle formation and corresponding contribution to cloud condensation nuclei production, Atmos. Chem. Phys., 14, 10249-10265, https://doi.org/10.5194/acp-14-102492014, 2014.

Qi, X. M., Ding, A. J., Nie, W., Petäjä, T., Kerminen, V.-M., Herrmann, E., Xie, Y. N., Zheng, L. F., Manninen, H., Aalto, P., Sun, J. N., Xu, Z. N., Chi, X. G., Huang, X., Boy, M., Virkkula, A., Yang, X.-Q., Fu, C. B., and Kulmala, M.: Aerosol size distribution and new particle formation in the western Yangtze River Delta of China: 2 years of measurements at the SORPES station, Atmos. Chem. Phys., 15, 12445-12464, https://doi.org/10.5194/acp-15-12445-2015, 2015.

Rose, C., Sellegri, K., Asmi, E., Hervo, M., Freney, E., Colomb, A., Junninen, H., Duplissy, J., Sipilä, M., Kontkanen, J., Lehtipalo, K., and Kulmala, M.: Major contribution of neutral clusters to new particle formation at the interface between the boundary layer and the free troposphere, Atmos. Chem. Phys., 15, 34133428, https://doi.org/10.5194/acp-15-3413-2015, 2015.

Saunders, R. W., Kumar, R., Martin, J. C. G., Mahajan, A. S., Murray, B. J., and Plane, J. M. C.: Studies of the Formation and Growth of Aerosol from Molecular Iodine Precursor, Z. Phys. Chem., 224, 1095-1117, https://doi.org/10.1524/zpch.2010.6143, 2010.

Shen, X. J., Sun, J. Y., Zhang, X. Y., Zhang, Y. M., Zhang, L., Fan, R. X., Zhang, Z. X., Zhang, X. L., Zhou, H. G., Zhou, L. Y., Dong, F., and Shi, Q. F.: The influence of emission control on particle number size distribution and new particle formation during China's V-Day parade in 2015, Sci. Total Environ., 573, 409419, https://doi.org/10.1016/j.scitotenv.2016.08.085, 2016.

Sihto, S.-L., Kulmala, M., Kerminen, V.-M., Dal Maso, M., Petäjä, T., Riipinen, I., Korhonen, H., Arnold, F., Janson, R., Boy, M., Laaksonen, A., and Lehtinen, K. E. J.: Atmospheric sulphuric acid and aerosol formation implications from atmospheric measurements for nucleation and early growth mechanisms, Atmos. Chem. Phys., 6, 4079-4091, https://doi.org/10.5194/acp-6-40792006, 2006.

Song, M., Lee, M., Kim, J. H., Yum, S. S., Lee, G., and Kim, K.-R.: New particle formation and growth in relation to vertical mixing and chemical species during ABC-EAREX2005, Atmos. Res., 97, 359-370, https://doi.org/10.1016/j.atmosres.2010.04.013, 2010. 
Sorribas, M., Adame, J. A., Olmo, F. J., Vilaplana, J. M., Gil-Ojeda, M., and Alados-Arboledas, L.: A long-term study of new particle formation in a coastal environment: meteorology, gas phase and solar radiation implications, Sci. Total Environ., 511, 723-737, https://doi.org/10.1016/j.scitotenv.2014.12.011, 2015.

Spracklen, D. V., Carslaw, K. S., Kulmala, M., Kerminen, V.-M., Sihto, S.-L., Riipinen, I., Merikanto, J., Mann, G. W., Chipperfield, M. P., Wiedensohler, A., Birmili, W., and Lihavainen, H.: Contribution of particle formation to global cloud condensation nuclei concentrations, Geophys. Res. Lett., 35, 160-162, https://doi.org/10.1029/2007gl033038, 2008.

Sun, L., Xue, L. K., Wang, T., Gao, J., Ding, A. J., Cooper, O. R., Lin, M. Y., Xu, P. J., Wang, Z., Wang, X. F., Wen, L., Zhu, Y. H., Chen, T. S., Yang, L. X., Wang, Y., Chen, J. M., and Wang, W. X.: Significant increase of summertime ozone at Mount Tai in Central Eastern China, Atmos. Chem. Phys., 16, 10637-10650, https://doi.org/10.5194/acp-16-10637-2016, 2016.

Venzac, H., Sellegri, K., Laj, P., Villani, P., Bonasoni, P., Marinoni, A., Cristofanelli, P., Calzolari, F., Fuzzi, S., Decesari, S., Facchini, M. C., Vuillermoz, E., and Verza, G. P.: High frequency new particle formation in the $\mathrm{Hi}-$ malayas, P. Natl. Acad. Sci. USA, 105, 15666-15671, https://doi.org/10.1073/pnas.0801355105, 2008.

Wang, D. W., Guo, H., Cheung, K., and Gan, F. X.: Observation of nucleation mode particle burst and new particle formation events at an urban site in Hong Kong, Atmos. Environ., 99, 196-205, https://doi.org/10.1016/j.atmosenv.2014.09.074, 2014.

Wang, H., Zhu, B., Shen, L., An, J., Yin, Y., and Kang, H.: Number size distribution of aerosols at Mt. Huang and Nanjing in the Yangtze River Delta, China: Effects of air masses and characteristics of new particle formation, Atmos. Res., 150, 42-56, https://doi.org/10.1016/j.atmosres.2014.07.020, 2014.

Wang, Z. B., Hu, M., Yue, D. L., Zheng, J., Zhang, R. Y., Wiedensohler, A., Wu, Z. J., Nieminen, T., and Boy, M.: Evaluation on the role of sulfuric acid in the mechanisms of new particle formation for Beijing case, Atmos. Chem. Phys., 11, 12663-12671, https://doi.org/10.5194/acp-11-12663-2011, 2011.

Wang, Z. B., Hu, M., Wu, Z. J., and Yue, D. L.: Reasearch on the Formation Mechanisms of New Particles in the Atmosphere, Acta. Chim. Sin., 71, 519-527, https://doi.org/10.6023/a12121062, 2013.

Wang, Z. B., Hu, M., Pei, X. Y., Zhang, R. Y., Paasonen, P., Zheng, J., Yue, D. L., Wu, Z. J., Boy, M., and Wiedensohler, A.: Connection of organics to atmospheric new particle formation and growth at an urban site of Beijing, Atmos. Environ., 103, 7-17, https://doi.org/10.1016/j.atmosenv.2014.11.069, 2015.

Wehner, B., Wiedensohler, A., Tuch, T. M., Wu, Z. J., Hu, M., Slanina, J., and Kiang, C. S.: Variability of the aerosol number size distribution in Beijing, China: New particle formation, dust storms, and high continental background, Geophys. Res. Lett., 31, L22108, https://doi.org/10.1029/2004g1021596, 2004.

Weingartner, E., Nyeki, S., and Baltensperger, U.: Seasonal and diurnal variation of aerosol size distributions $(10<D<750 \mathrm{~nm})$ at a high-alpine site (Jungfraujoch $3580 \mathrm{masl}$ ), J. Geophys. Res., 104, 26809-26820, https://doi.org/10.1029/1999jd900170, 1999.
Wu, Z., Hu, M., Liu, S., Wehner, B., Bauer, S., Ma ßling, A., Wiedensohler, A., Petäjä, T., Dal Maso, M., and Kulmala, M.: New particle formation in Beijing, China: Statistical analysis of a 1-year data set, J. Geophys. Res., 112, 9209, https://doi.org/10.1029/2006jd007406, 2007.

Xiao, S., Wang, M. Y., Yao, L., Kulmala, M., Zhou, B., Yang, X., Chen, J. M., Wang, D. F., Fu, Q. Y., Worsnop, D. R., and Wang, L.: Strong atmospheric new particle formation in winter in urban Shanghai, China, Atmos. Chem. Phys., 15, 1769-1781, https://doi.org/10.5194/acp-15-1769-2015, 2015.

Yue, D. L., Hu, M., Zhang, R. Y., Wang, Z. B., Zheng, J., Wu, Z. J., Wiedensohler, A., He, L. Y., Huang, X. F., and Zhu, T.: The roles of sulfuric acid in new particle formation and growth in the mega-city of Beijing, Atmos. Chem. Phys., 10, 4953-4960, https://doi.org/10.5194/acp-10-4953-2010, 2010.

Yue, D. L., Hu, M., Wang, Z. B., Wen, M. T., Guo, S., Zhong, L. J., Wiedensohler, A., and Zhang, Y. H.: Comparison of particle number size distributions and new particle formation between the urban and rural sites in the PRD region, China, Atmos. Environ., 76, 181-188, https://doi.org/10.1016/j.atmosenv.2012.11.018, 2013.

Zhang, R.: Getting to the Critical Nucleus of Aerosol Formation, Science, 328, 1366-1367, 2010.

Zhang, R., Suh, I., Zhao, J., Zhang, D., Fortner, E. C., Tie, X., Molina, L. T., and Molina, M. J.: Atmospheric new particle formation enhanced by organic acids, Science, 304, 1487-1490, https://doi.org/10.1126/science.1095139, 2004.

Zhang, R., Khalizov, A., Wang, L., Hu, M., and Xu, W.: Nucleation and growth of nanoparticles in the atmosphere, Chem. Rev., 112, 1957-2011, https://doi.org/10.1021/cr2001756, 2012.

Zhang, X., Yin, Y., Lin, Z., Han, Y., Hao, J., Yuan, L., Chen, K., Chen, J., Kong, S., Shan, Y., Xiao, H., and Tan, W.: Observation of aerosol number size distribution and new particle formation at a mountainous site in Southeast China, Sci. Total Environ., 575, 309-320, https://doi.org/10.1016/j.scitotenv.2016.09.212, 2016.

Zhang, X. H., Zhang, Y. M., Sun, J. Y., Zheng, X. J., Li, G., and Deng, Z. Q.: Characterization of particle number size distribution and new particle formation in an urban environment in Lanzhou, China, J. Aerosol Sci., 103, 53-66, https://doi.org/10.1016/j.jaerosci.2016.10.010, 2017.

Zhang, Y. M., Zhang, X. Y., Sun, J. Y., Lin, W. L., Gong, S. L., Shen, X. J., and Yang, S.: Characterization of new particle and secondary aerosol formation during summertime in Beijing, China, Tellus B, 63, 382-394, https://doi.org/10.1111/j.16000889.2011.00533.x, 2011.

Zhang, Y. M., Zhang, X. Y., Sun, J. Y., Hu, G. Y., Shen, X. J., Wang, Y. Q., Wang, T. T., Wang, D. Z., and Zhao, Y.: Chemical composition and mass size distribution of $\mathrm{PM}_{1}$ at an elevated site in central east China, Atmos. Chem. Phys., 14, 12237-12249, https://doi.org/10.5194/acp-14-12237-2014, 2014.

Zhu, Y., Sabaliauskas, K., Liu, X., Meng, H., Gao, H., Jeong, C.-H., Evans, G. J., and Yao, X.: Comparative analysis of new particle formation events in less and severely polluted urban atmosphere, Atmos. Environ., 98, 655-664, https://doi.org/10.1016/j.atmosenv.2014.09.043, 2014. 